\title{
Lack of neuroprotection in the absence of P2X7 receptors in toxin-induced animal models of Parkinson's disease
}

\author{
Zsuzsanna Hracskó $^{1 \dagger}$, Mária Baranyi ${ }^{1 \dagger}$, Cecilia Csölle$^{1}$, Flóra Gölöncsér ${ }^{1}$, Emilia Madarász ${ }^{2}$, Ágnes Kittel ${ }^{1}$ and \\ Beáta Sperlágh ${ }^{1 *}$
}

\begin{abstract}
Background: Previous studies indicate a role of $\mathrm{P}_{2} \mathrm{X}_{7}$ receptors in processes that lead to neuronal death. The main objective of our study was to examine whether genetic deletion or pharmacological blockade of $\mathrm{P} 2 \mathrm{X}_{7}$ receptors influenced dopaminergic cell death in various models of Parkinson's disease (PD).

Results: mRNA encoding $P 2 X_{7}$ and $P 2 X_{4}$ receptors was up-regulated after treatment of PC12 cells with 1-methyl-4phenyl-1,2,3,6- tetrahydropyridine (MPTP). P2X 7 antagonists protected against MPTP and rotenone induced toxicity in the LDH assay, but failed to protect after rotenone treatment in the MTT assay in PC12 cells and in primary midbrain culture. In vivo MPTP and in vitro rotenone pretreatments increased the mRNA expression of P2X

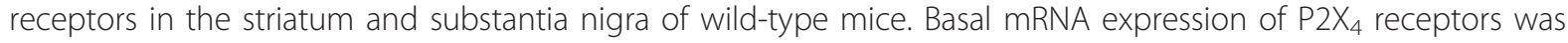
higher in $\mathrm{P}_{2} \mathrm{X}_{7}$ knockout mice and was further up-regulated by MPTP treatment. Genetic deletion or pharmacological inhibition of $\mathrm{P}_{2} \mathrm{X}_{7}$ receptors did not change survival rate or depletion of striatal endogenous dopamine (DA) content after in vivo MPTP or in vitro rotenone treatment. However, depletion of norepinephrine was significant after MPTP treatment only in P2X $X_{7}$ knockout mice. The basal ATP content was higher in the substantia nigra of wild-type mice, but the ADP level was lower. Rotenone treatment elicited a similar reduction in ATP content in the substantia nigra of both genotypes, whereas reduction of ATP was more pronounced after rotenone treatment in striatal slices of $\mathrm{P} 2 \mathrm{X}_{7}$ deficient mice. Although the endogenous amino acid content remained unchanged, the level of the endocannabinoid, 2-AG, was elevated by rotenone in the striatum of wild-

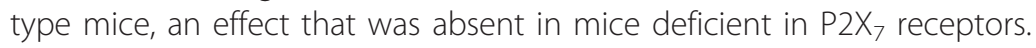

Conclusions: We conclude that $\mathrm{P} 2 \mathrm{X}_{7}$ receptor deficiency or inhibition does not support the survival of dopaminergic neurons in an in vivo or in vitro models of PD.

\section{Background}

The role of extracellular ATP and purinoceptors in neurodegeneration is the focus of a promising area of research [1-3]. $\mathrm{P} 2 \mathrm{X}_{7}$ receptors belong to the ionotropic $\mathrm{P} 2 \mathrm{X}$ receptors [4], which are sensitive to ATP and other nucleotides. The homo-oligomeric $\mathrm{P}_{2} \mathrm{X}_{7}$ receptor has distinct structural, functional and pharmacological features within the P2X receptor family [2,3,5]: (1) its intracellular carboxy terminal domain is longer than the

\footnotetext{
* Correspondence: sperlagh@koki.hu

+ Contributed equally

'Laboratory of Molecular Pharmacology, Institute of Experimental Medicine, Hungarian Academy of Sciences, H-1083 Budapest, Szigony u. 43, Hungary Full list of author information is available at the end of the article
}

other P2X receptor subunits; (2) it has several splice variants that display distinct functionalities in $\mathrm{P}_{2} \mathrm{X}_{7}$ receptor wild-type and knockout mice [6]; (3) its persistent activation elicits the opening of a membrane pore, which eventually leads to cell death in certain cell types; and (4) it needs high micromolar concentrations of ATP to be activated.

$\mathrm{P}_{2} \mathrm{X}_{7}$ receptors probably affect neuronal death and survival in a complex way. An important role of $\mathrm{P} 2 \mathrm{X}_{7}$ receptors in the brain is the modulation of neurotransmitter release [3,7]. The activation of $\mathrm{P} 2 \mathrm{X}_{7}$ receptors elicits $\mathrm{Ca}^{2+}$ influx, which is followed by increased glutamate and subsequent GABA release [8-10] that could reinforce glutamate-mediated excitotoxicity under

\section{Biomed Central}


pathological conditions. In addition, $\mathrm{P}_{2} \mathrm{X}_{7}$ receptors play a governing role in the activation and proliferation of microglia following pathological signals $[11,12]$ and directly contribute to neurodegeneration by eliciting microglia-mediated neuronal death [13]. Moreover, $\mathrm{P}_{2} \mathrm{X}_{7}$ receptors are involved in the processing and release of other key mediators in neurodegeneration, such as interleukin-1 $\beta,[2,14]$, and in the production of endocannabinoids, which are neuroprotective. In fact, $\mathrm{P}_{2} \mathrm{X}_{7}$ receptor activation is one of the most powerful stimuli that lead to the synthesis and subsequent release of endocannabinoids from activated microglia [15] and astrocytes [16].

Accordingly, the blockade or absence of $\mathrm{P}_{2} \mathrm{X}_{7}$ receptors were found to be neuroprotective in animal models of spinal cord injury $[17,18]$, Alzheimer's disease (AD) [19] and Huntington's disease [20], but conflicting results have been found in animal models of ischemiareperfusion $([21,22]$ but see $[23,24])$ and multiple sclerosis ([25] but see [26,27]). However, data regarding $\mathrm{P}^{2} \mathrm{X}_{7}$ receptors in the striatum and its role in PD are scarce. In dopaminergic co-cultures, PCR data indicate the expression of $\mathrm{P}_{2} \mathrm{X}_{7}$ mRNA in neonatal and adult rats [28], and the presence of $\mathrm{P}_{2} \mathrm{X}_{7}$ receptor protein has also identified in the rat brain striatum and substantia nigra [29]. Functional $\mathrm{P} \mathrm{X}_{7}$ receptors have been detected in synaptosomal preparations from the rat midbrain [30] and in organotypic striatal cultures [31]. In SN4741 dopaminergic cells, ATP-induced swelling and cell death are reversed by the $\mathrm{P}_{2} \mathrm{X}_{7}$ receptor antagonist, KN62, or by the knock-down of $\mathrm{P}_{2} \mathrm{X}_{7}$ receptors with small interfering RNAs [32]. Nevertheless, evidence of a protective or aggravating role of $\mathrm{P}_{2} \mathrm{X}_{7}$ receptors in an in vivo animal model of PD is still lacking.

This work provides insight on the effect of $\mathrm{P}_{2} \mathrm{X}_{7}$ receptor deficiency in different models of $\mathrm{PD}$. The mRNA encoding $\mathrm{P}_{2} \mathrm{X}_{7}$ receptors was up-regulated after rotenone or MPTP treatment in PC12 cells and in the striatum, but these changes were not translated to $\mathrm{P}_{2} \mathrm{X}_{7}$ receptor protein expression in the striatum. Although $\mathrm{P}_{2} \mathrm{X}_{7}$ receptor antagonists displayed some protective effect against rotenone-induced toxicity in PC12 cells, these data could not be replicated in primary dopaminergic neurons, in MPTP-induced toxicity or in an in vitro and an in vivo animal model of PD.

\section{Results}

Effect of in vitro MPTP treatment on the expression of $\mathrm{P} 2 \mathrm{X}_{7}$ and $\mathrm{P} 2 \mathrm{X}_{4}$ receptors

Changes in the levels of mRNA transcripts of the $\mathrm{P}_{2} \mathrm{X}_{7}$ and $\mathrm{P}_{2} \mathrm{X}_{4}$ receptor subunits were measured using realtime RT-PCR in PC12 cells after $24 \mathrm{~h}$ of a $1 \mu \mathrm{M}$ in vitro MPTP treatment (Figures 1A, B). Gene expression level was normalized to the expression level of the $18 \mathrm{~S}$ rRNA reference gene. Quantitative real-time PCR measurements revealed that the mRNA expression of the $\mathrm{P} 2 \mathrm{X}_{7}$ receptor was up-regulated to $2.65 \pm 0.55$ of the corresponding control values, established as 1 and normalized to $18 \mathrm{~S}$ rRNA (Figure $1 \mathrm{~A} ; \mathrm{n}=5, P<0.05$ ). Likewise, the expression level of the $\mathrm{P}_{2} \mathrm{X}_{4}$ receptor was up-regulated to $1.69 \pm 0.22$ of the corresponding control values (Figure $1 \mathrm{~B} ; n=5, P<0.05)$.

\section{Effect of $\mathrm{P} 2 \mathrm{X}_{7}$ receptor antagonists on rotenone and MPTP-induced inhibition of cell viability in PC12 cells}

In conjunction with our previous study [33], treatment of PC12 cells with the mitochondrial complex I inhibitor, rotenone, elicited a concentration-dependent (0.01$30 \mu \mathrm{M})$ decline in cell viability, measured by the MTT assay, that resulted in a significant decrease to $79.2 \pm$ $3.7 \%$ of the control after a $20 \mathrm{~h}$ treatment with a $1 \mu \mathrm{M}$ concentration $(\mathrm{n}=4, \mathrm{P}<0.01$, Figures $1 \mathrm{C}, \mathrm{E})$. The same treatment elevated the amount of released $\mathrm{LDH}$, another indicator of cellular death, to $169.71 \pm 8.91 \%$ ( $n=4, P<$ 0.01) (Figure 1G). The treatment of the cells with MPTP also concentration-dependently (0.01-30 $\mu \mathrm{M})$ decreased cell viability in the MTT assay (Figure 1D). The decrease in cell survival reached a significant level at 10 $\mu \mathrm{M}$ concentration $(60.68 \pm 1.07 \%, \mathrm{n}=40, \mathrm{P}<0.01$, Figures $1 \mathrm{D}, \mathrm{F})$. This treatment also elicited a significant increase in the amount of released LDH (137.42 \pm $9.08 \%, \mathrm{n}=8, \mathrm{P}<0.01$, Figure $1 \mathrm{H})$. The MAO-B inhibitor, L-deprenyl (10-100 nM), displayed significant protection against the decrease in cell viability elicited by rotenone measured either by using the MTT (Figure 1E) or the LDH assays (Figure 1G). A consistent protective effect was also observed after MPTP treatment (Figures $1 F, H)$. Pretreatment with the selective $\mathrm{P}_{2} \mathrm{X}_{7}$ receptor antagonists, BBG (10 and $100 \mathrm{nM}$ ) and AZ10606120 (10 and $100 \mathrm{nM}$ ) had no effect on cell viability after rotenone treatment when measured with the MTT assay (Figure 1E). However, identical treatments with the $\mathrm{P}_{2} \mathrm{X}_{7}$ receptor antagonists significantly attenuated the effect of MPTP in the MTT assay (Figure 1F) and the effect of both rotenone (Figure 1G) and MPTP (Figure $1 \mathrm{H})$ in the LDH assay.

\section{Effect of $\mathrm{P}_{2} \mathrm{X}_{7}$ receptor antagonists on rotenone- and MPTP-induced inhibition of cell viability in primary midbrain cultures}

Because the molecular machinery of degeneration of PC12 cells and dopaminergic neurons are not necessarily the same, we next sought to determine how $\mathrm{P}_{2} \mathrm{X}_{7}$ receptor antagonists affect cell viability in primary substantia nigra cultures that contain dopaminergic neurons, which can be identified by tyrosine hydroxylase immunoreactivity. As shown in Figures 2A-C, MAP2positive neurons displayed strong tyrosine hydroxylase 
A

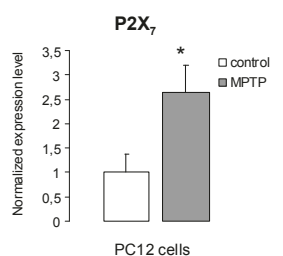

C

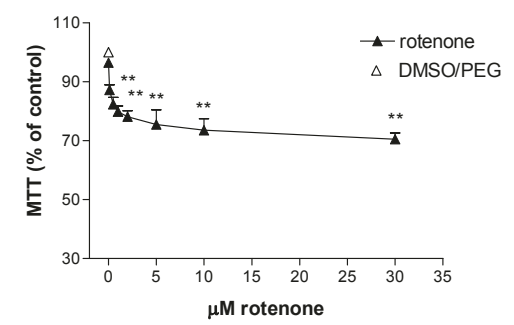

E

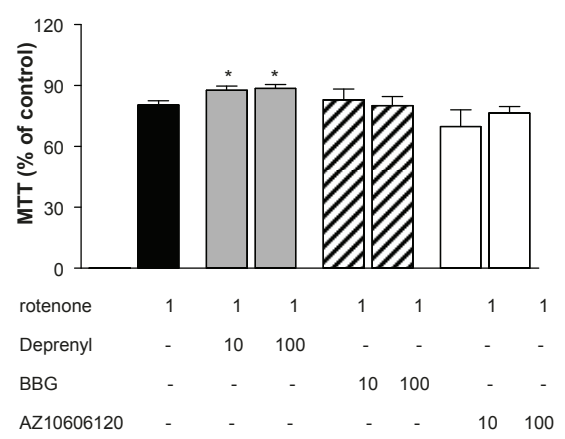

G

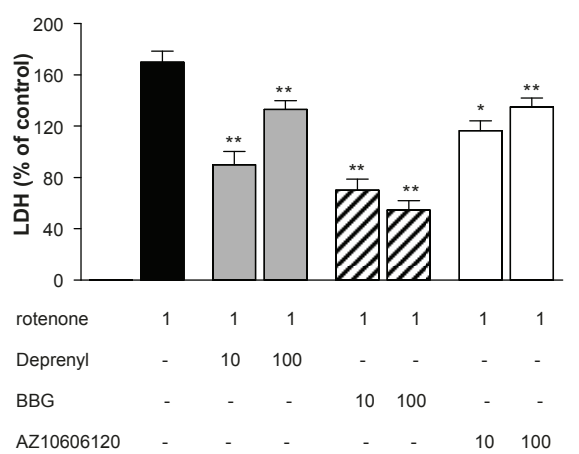

B



D
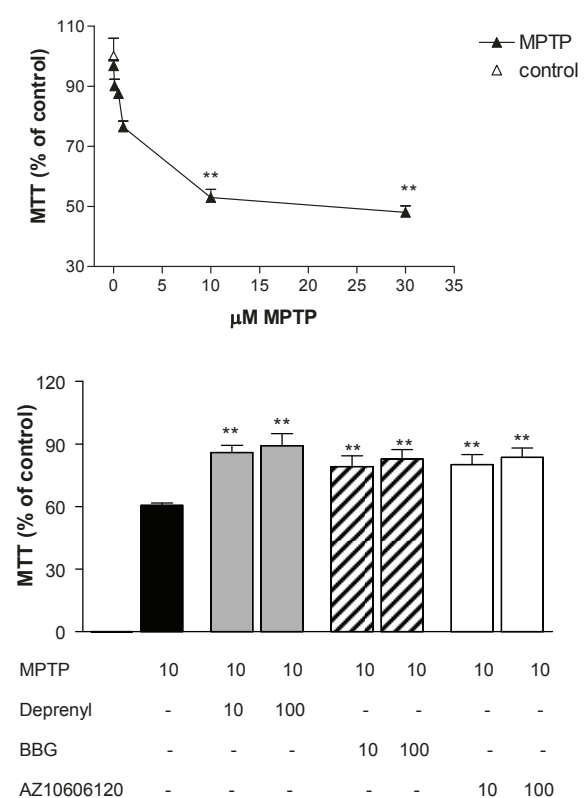

H

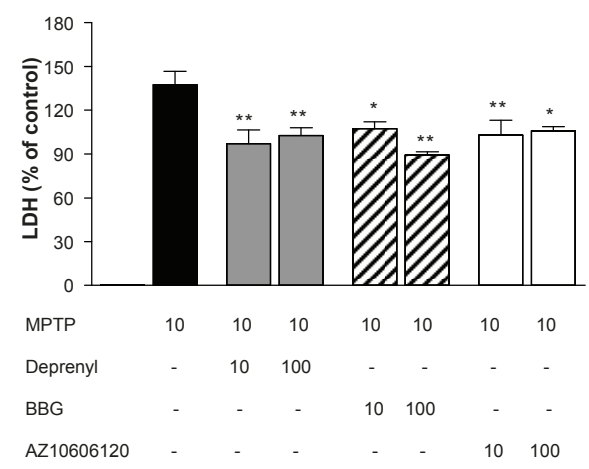

Figure 1 Effect of $\mathrm{P} 2 \mathrm{X}_{7}$ receptor antagonists on cell viability after rotenone and MPTP pretreatment in PC12 cells. A. and B. Expression levels of the P2X $X_{7}(A)$ and P2X (B) purinergic receptors in PC12 cells after $1 \mu \mathrm{M}$ MPTP treatment. Quantitative SYBR Green real-time PCR was performed using specific primers. The experiments were repeated twice with similar results. The expression level of the P2X receptors was normalized to the expression level of the distinct housekeeping gene, $18 \mathrm{~S}$ rRNA. Data are displayed as the mean \pm S.E.M. Asterisks indicate significant differences from the corresponding control ${ }^{*} P<0.05$, Student's t-test). C and D. Concentration-dependent inhibition of cell viability by rotenone (C) and MPTP (D) in the MTT assay. Cells were treated with various concentrations of the toxins ranging from $0.01 \mu \mathrm{M}$ to $30 \mu \mathrm{M}$, and the reduction of MTT into formazan was measured $20 \mathrm{~h}$ later. Cell viability is expressed as a percentage of the respective controls. E and F. Effects of BBG and AZ10606120 on toxicity induced by rotenone (E) and MPTP (F) measured in the MTT assay. Cells were pretreated with Ldeprenyl and with the P2X antagonists, BBG and AZ10606120, in 10 and $100 \mathrm{nM}$ concentrations for $1 \mathrm{~h}$ before treatment with $1 \mu \mathrm{M}$ rotenone or $10 \mu \mathrm{M}$ MPTP for $20 \mathrm{~h}$. Data are expressed as the percentage of values of control cultures and are the means \pm S.E.M. of four experiments. G. and $\mathrm{H}$. Effects of BBG and AZ10606120 on toxicity induced by rotenone (G) and MPTP (H) measured in the LDH assay. Treatments of the cells were identical to the MTT assay. The released LDH is expressed as the percentage of total LDH measured after freeze/thaw lysis of cells. These data are then expressed as the percentage of values of control cultures and are the means \pm S.E.M. of four experiments. ${ }^{*} P<0.05,{ }^{* *} P<0.01$, significance vs. controls using an ANOVA followed by the Dunnett test. E-H. Note that the concentration of rotenone and MPTP are indicated in $\mu \mathrm{M}$, whereas the concentration of other drugs in $\mathrm{nM}$. 

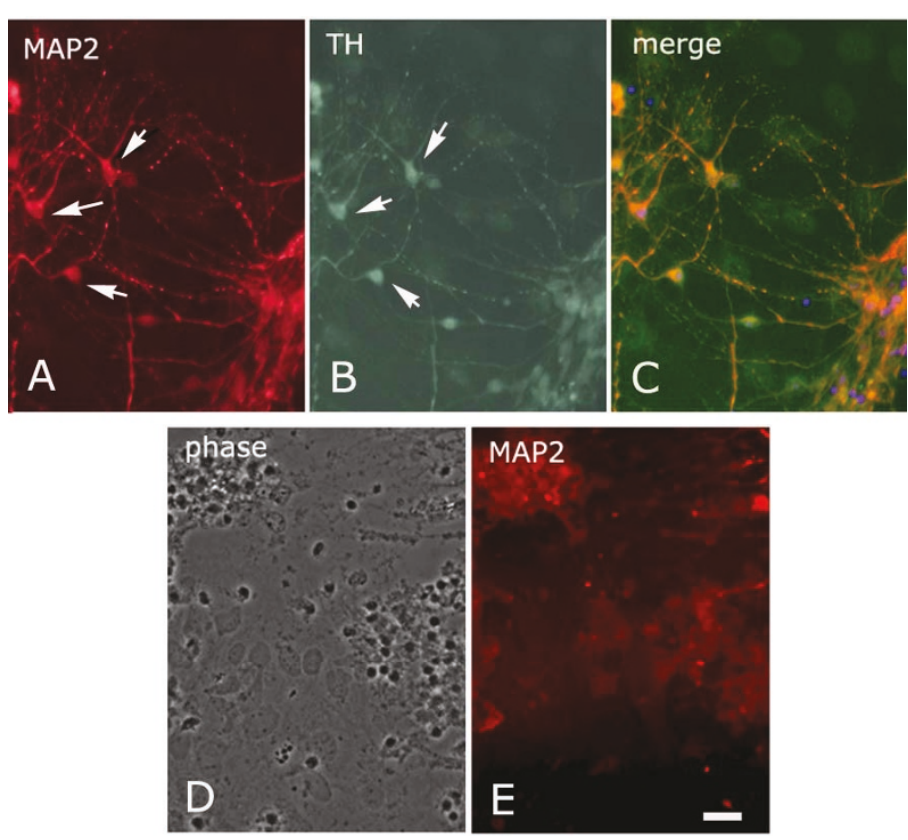

$\mathbf{F}$

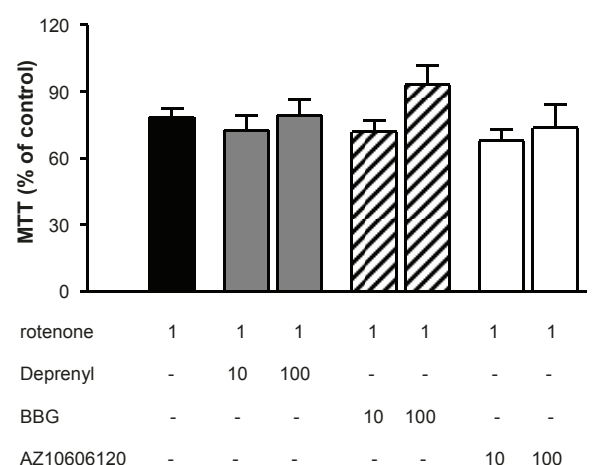

G

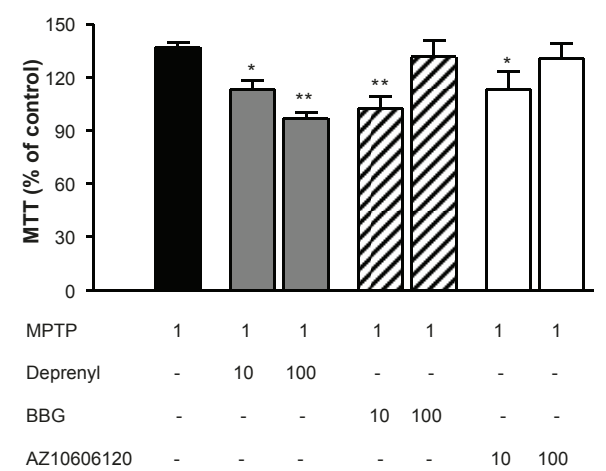

Figure 2 Effect of $\mathrm{P}_{2} \mathrm{X}_{7}$ receptor antagonists on cell viability after rotenone and MPTP pretreatment in primary substantia nigra (SN) culture. Non-treated SN cultures contained large tyrosine hydroxylase-positive (arrow) neurons that were identified by MAP2 (red; A) and TH (green; B) immunoreactivity (merge; C). Rotenone treatment disrupted the neurons (phase contrast morphology; D and MAP2 immunostaining; E). Scale bar: $20 \mu \mathrm{m}$. MAP2+ and TH+ neurons represented $26.28 \pm 10.6 \%$ and $7.32 \pm 2.81 \%$ of the total cell number. Total cell number was determined by counting DAPI-positive nuclei on each of 40 microscopic fields. Cells were counted at $250 \times(2 \times 10$ fields $)$ and $500 \times(2 \times 10$ fields) magnification (independent determinations: $n=4$ ). F. and $G$. Effects of BBG and AZ10606120 on changes in cell viability induced by rotenone (F) and MPTP $(G)$ measured in the MTT assay. Cells were pretreated with L-deprenyl and with the P2X $X_{7}$ antagonists, BBG and AZ10606120, in 10 and $100 \mathrm{nM}$ concentrations for $1 \mathrm{~h}$ before treatment with $1 \mu \mathrm{M}$ rotenone or MPTP for $20 \mathrm{~h}$. Data are expressed as the percentage of values of control cultures and are the means \pm S.E.M. of four experiments. ${ }^{*} P<0.05$, ${ }^{*} P<0.01$, significance vs. controls using an ANOVA followed by the Dunnett test. Note that the concentration of rotenone and MPTP are indicated in $\mu \mathrm{M}$, whereas the concentration of other drugs in $\mathrm{nM}$. 
immunoreactivity in the culture after 8 days in vitro. Similar to what we observed in PC12 cells, the treatment of cultures with rotenone $(1 \mu \mathrm{M})$ elicited a significant decline in cell viability when measured in the MTT assay (78.24 $\pm 4.15 \%, \mathrm{n}=7, \mathrm{P}=0.05$, Figure $2 \mathrm{~F})$. The morphological destruction of MAP2 neurons was also clearly observed (Figures 2D, E). Using this model, we did not observe any protective effect using deprenyl, BBG or AZ10606120 (Figure 2F). Interestingly, MPTP (1 $\mu \mathrm{M})$ caused an elevation of cell viability in these experiments $(136.8 \pm 2.49 \%, n=7, P<0.01$, Figure $2 G)$, and L-deprenyl (10-100 nM), BBG (10 nM) and AZ10606120 (10 $\mathrm{nM}$ ) attenuated these effects (Figure $2 \mathrm{G}$ ).

\section{Effect of in vivo MPTP treatment on the expression of $\mathrm{P}_{2} \mathrm{X}_{\mathbf{7}}$ and $\mathrm{P} 2 \mathrm{X}_{4}$ purinergic receptors}

Similar to what was seen after in vitro MPTP treatment, the in vivo treatment of WT mice with the dopaminergic neurotoxin, MPTP $(4 \times 20 \mathrm{mg} / \mathrm{kg}$ i.p. $)$, caused an up-regulation of the mRNA levels of the $\mathrm{P}_{2} \mathrm{X}_{7}$ receptor in the striatum to $3.45 \pm 0.95$ of the corresponding control values (Figure 3A, $\mathrm{n}=8, P<0.05$ ). Likewise, mRNA encoding $\mathrm{P}_{2} \mathrm{X}_{7}$ receptor was strongly up-regulated to $8.70 \pm 0.34$ of the corresponding control values, established as 1 , normalized to $18 \mathrm{~S}$ rRNA in the substantia nigra (Figure $3 \mathrm{~B}, \mathrm{n}=4, \mathrm{P}<0.0001$ ). The expression level of the $\mathrm{P}_{2} \mathrm{X}_{4}$ receptor was up-regulated both in

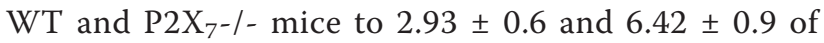
the corresponding control values (Figure $3 \mathrm{C}, \mathrm{n}=6, \mathrm{P}<$ $0.05)$. It is noteworthy that the basal expression of the $\mathrm{P}_{2} \mathrm{X}_{4}$ receptor in $\mathrm{P}_{2} \mathrm{X}_{7} /$ - mice was also significantly elevated $(3.75 \pm 0.8, \mathrm{n}=6, P<0.05)$ compared to the basal expression level of the WT group (Figure $3 \mathrm{C}$ ). When the expression of $\mathrm{P}_{2} \mathrm{X}_{7}$ receptors in the striatum was examined at the protein level using a specific antibody, a relatively weak $\mathrm{P} 2 \mathrm{X}_{7}$ receptor immunoreactivity was found in the striatum, in agreement with a previous study in rats [29]. Punctate immunostaining was observed throughout the striatum and was co-localized to microglial cells, which were identified by GSL I - isolectin B4 marker in saline-treated WT mice (Figure 3D). No apparent change in the expression of $\mathrm{P} 2 \mathrm{X}_{7}$ receptor was visible in striatal slices derived from WT mice that had undergone in vivo MPTP treatment; if any, only a slight decrease in its expression was observed (Figure $3 \mathrm{E})$. The staining intensity of $\mathrm{P}_{2} \mathrm{X}_{7}$ receptor immunoreactivity was identical with the background in striatal slices prepared from $\mathrm{P}_{2} \mathrm{X}_{7}-/$ - mice treated with saline (Figure 3F).

\section{Effect of in vivo MPTP treatment on biogenic amine content of the striatum}

HPLC analysis of the tissue content of DA and its metabolites, DOPAC, HVA, norepinephrine (NE) and 3- methoxytyramine (3-MT), and that of serotonin (5-HT) and 5-hydroxyindoleacetic acid (5-HIAA) showed that, in saline-treated animals, DA, HVA and 3-MT levels were significantly higher in mice genetically deficient in $\mathrm{P}_{2} \mathrm{X}_{7}$ receptors compared to WT mice (Figures 4A, B). We then examined how MPTP treatment (4 x10-20 mg/ kg i.p.) in WT and $\mathrm{P}_{2} \mathrm{X}_{7} / /$ - mice changed the levels of these compounds. MPTP caused a dose-dependent and profound depletion of DA content in the WT group, which represents a biochemical feature of PD. Similar to $\mathrm{DA}$, there was a significant decline in the amount of DA metabolites (e.g., DOPAC, 3-MT) in the WT group, but no significant decline in the amount of NE was observed (Figures $4 \mathrm{~A}, \mathrm{~B}$ ). In the $\mathrm{P} 2 \mathrm{X}_{7}-/$ - mice, MPTP treatment elicited a similar reduction of endogenous DA content as the WT mice (Figure 4A). Moreover, in the $\mathrm{P}^{2} \mathrm{X}_{7}-/$ group, the reduction of NE, HVA and 3-MT levels after MPTP treatment was significant, and these changes were manifest at the lower dose of MPTP treatment (Figures 4A, B). In contrast, the content of DOPAC did not change after MPTP treatment in $\mathrm{P}_{2} \mathrm{X}_{7}$ receptor deficient animals (Figure 4B). 5-HT and its metabolite (5HIAA) were decreased in the WT mice, whereas in the $\mathrm{P}_{2} \mathrm{X}_{7}$-/- group, 5-HT levels were preserved after MPTP treatment and only 5-HIAA was depleted (Figure 4C).

Treatment with the higher dose $(4 \times 20 \mathrm{mg} / \mathrm{kg})$ of MPTP elicited a significant reduction of the survival of WT mice at the $72 \mathrm{~h}$ endpoint of the study (9 out of 16 animals, $56.25 \%, \mathrm{P}<0.01)$ compared to saline-treated animals (13 out of 13 animals, 100\%). Genetic deletion of $\mathrm{P}_{2} \mathrm{X}_{7}$ receptors alone did not change mortality in the saline-treated group (10 out of 10 animals, 100\%). A decrease in survival after MPTP $(4 \times 20 \mathrm{mg} / \mathrm{kg})$ treatment was also evident in $\mathrm{P}^{2} \mathrm{X}_{7^{-}} /$- mice ( 8 out of 16 animals, $50 \%, \mathrm{P}=0.03)$, but this effect was not significantly different from the WT group ( $P>0.05$, Figure 4D). The lower dose of MPTP treatment $(4 \times 10 \mathrm{mg} / \mathrm{kg}$ i.p. $)$ did not change the survival rate either in WT ( 6 out of 6 animals, $100 \%$ ) or $\mathrm{P}^{2} \mathrm{X}_{7-/-}$ mice (6 out of 6 animals, $100 \%)$.

When mice were pretreated with the $\mathrm{P} 2 \mathrm{X}_{7}$ receptor antagonist BBG in a dose previously shown to be protective in animal models of HD [20] and spinal cord injury [17], endogenous DA levels were depleted by MPTP compared to saline-treated mice (Fig. 4E) similar to what was observed in mice treated only with MPTP (Figure 4A). Likewise, a reduction of DOPAC levels was also observed in mice pretreated with BBG $18 \mathrm{~h}$ before MPTP treatment (Figure 4E).

\section{In vitro rotenone treatment}

Striatal slices of WT mice were preincubated in vitro with the irreversible complex I inhibitor, rotenone (10 $\mu \mathrm{M})$, for $60 \mathrm{~min}$. Changes in the levels of mRNA 


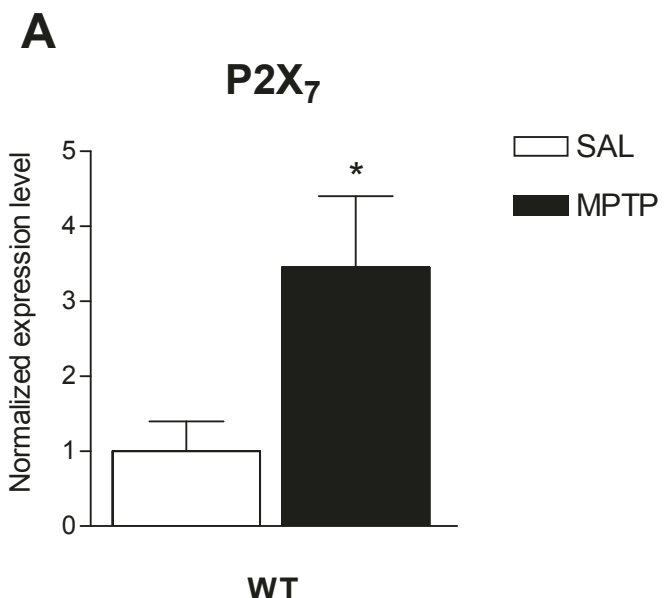

striatum
B

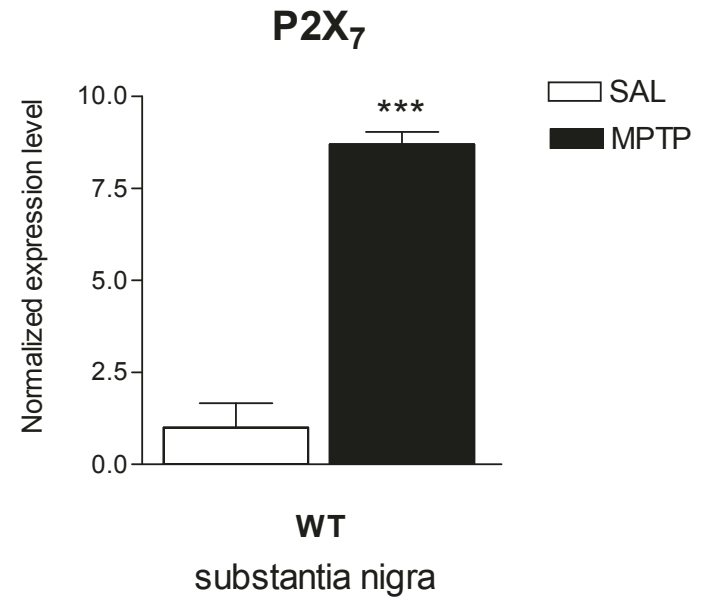

C

$\mathrm{P}^{2} \mathrm{X}_{4}$
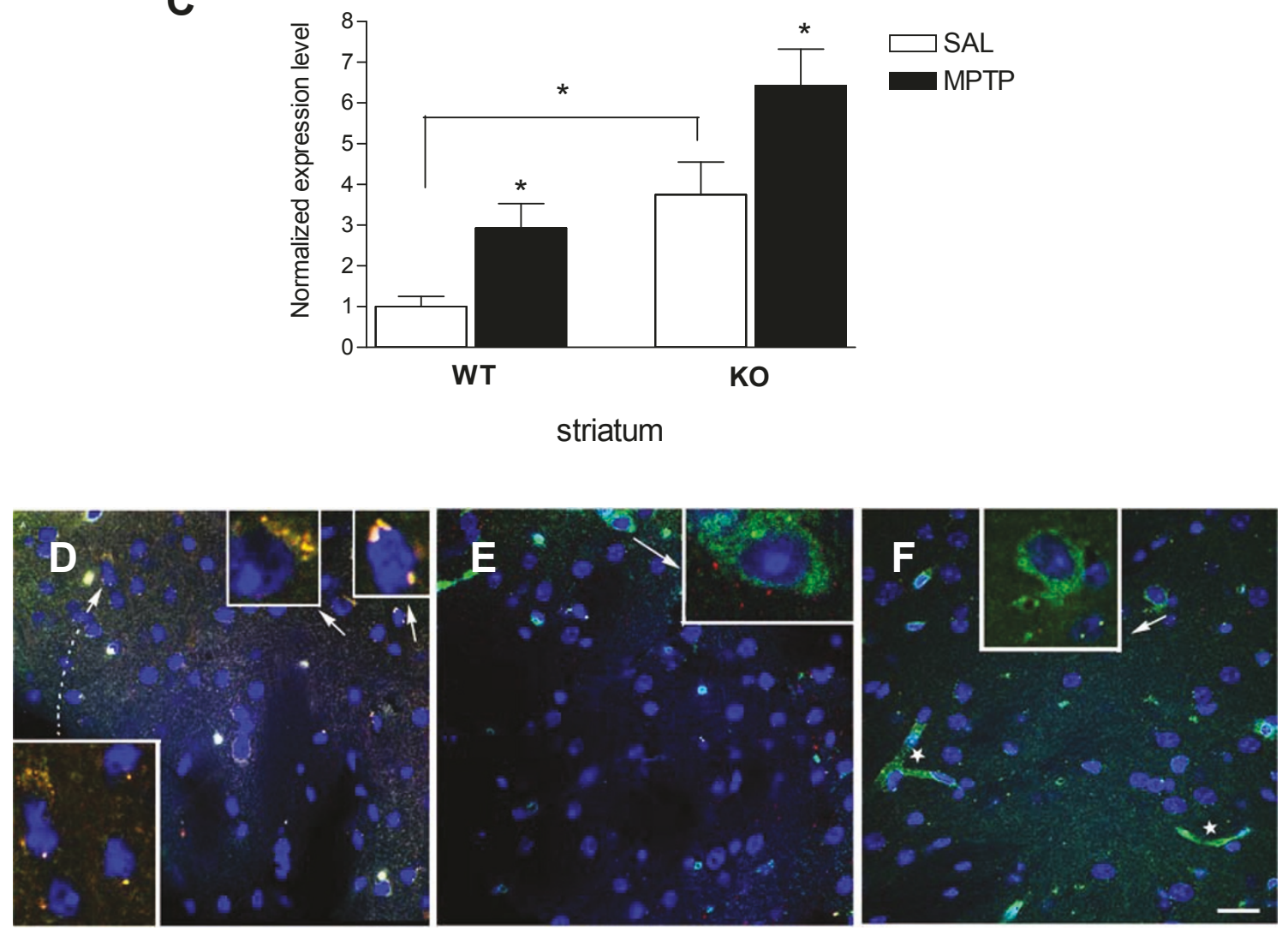

Figure 3 Changes in the mRNA and protein expression of $\mathrm{P} 2 \mathrm{X}_{7}$ and $\mathrm{P} 2 \mathrm{X}_{4}$ receptors in the striatum and substantia nigra obtained from $\mathrm{P}_{2} \mathrm{X}_{7}$ receptor wild-type (WT) and $\mathrm{P}_{2} \mathrm{X}_{\mathbf{7}} / \mathrm{I}_{-}(\mathrm{KO})$ mice after in vivo MPTP treatment. Mice (6-8 mice per group) were injected i.p. with $4 \times 20 \mathrm{mg} / \mathrm{kg}$ of MPTP or saline (SAL). A-C. After decapitation, the brains were removed immediately, total RNA extracted from the striatum (A, C) and substantia nigra (B) and then reverse-transcribed to CDNA. Data are displayed as the means \pm S.E.M. Asterisks indicate significant differences from the corresponding saline-injected mice or between genotypes as indicated $\left({ }^{*} P<0.05,{ }^{* * *}<0.0001\right)$. D, E. and F.

Immunofluorescent staining for $\mathrm{P}_{2} \mathrm{X}_{7}$ receptor and microglial cells in striatal sections of saline- and MPTP-treated WT and P2X $\mathrm{X}_{7} /-$ mice. Merged pictures. Fluorescein-labeled GSL I - isolectin B4 is a marker for endothelial (see stars in picture "F") and microglial cells. P2X $X_{7}$ receptors were labeled with a P2X-DyLight 549 conjugate (red). Orange means the same localization for both stains. DAPI (in Vectashield mounting medium) labels nuclei (blue). Scale bar: $20 \mu \mathrm{m}$. D. Detail of the striatal section of saline-treated WT mouse brain. Inserts (arrows) show the localization of P2X 7 receptors in FITC-labeled microglial cells. E. Only microglial cells are labeled (green, insert, arrow) in the striatal section of MPTP-treated WT mouse brain. F. Microglia (arrow, insert) and endothelial cells (stars) are labeled by the isolectin, but no P2X immunofluorescence is visible in the striatal sections of saline-treated $\mathrm{P} 2 \mathrm{X}_{7}-/$ - mouse brain. 


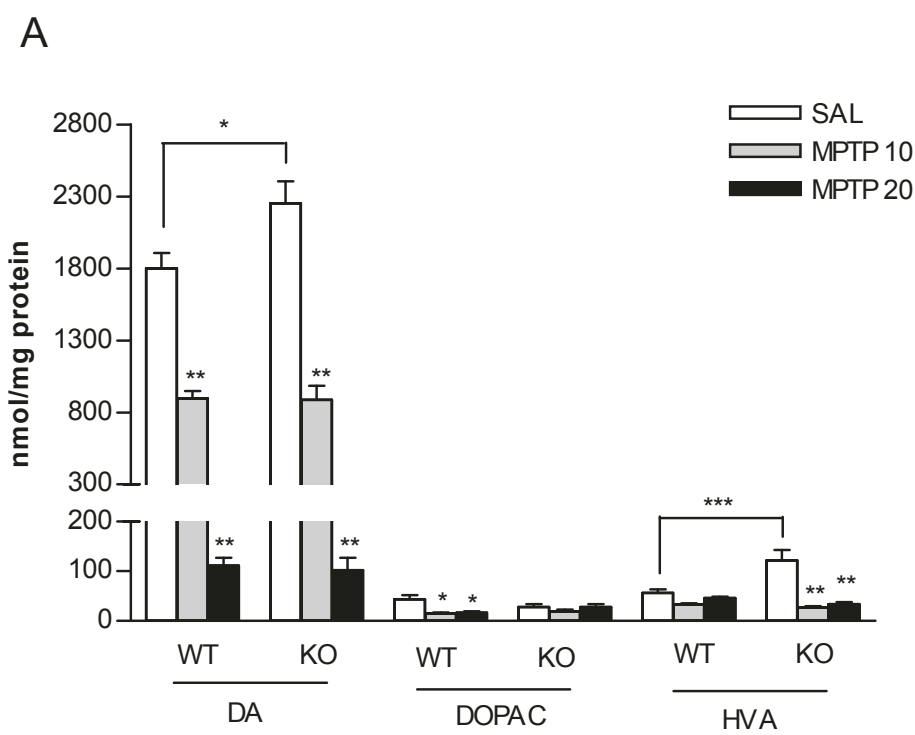

B

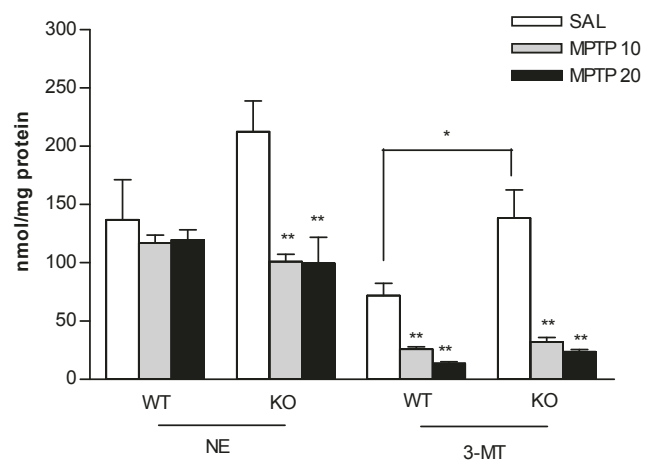

$\mathrm{D}$

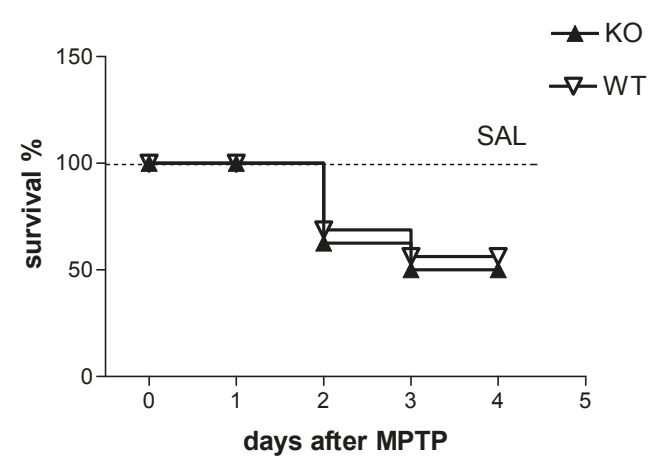

C

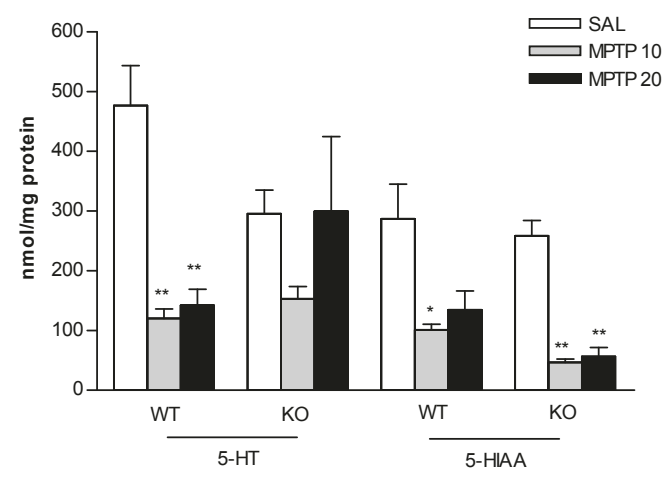

$\mathrm{E}$

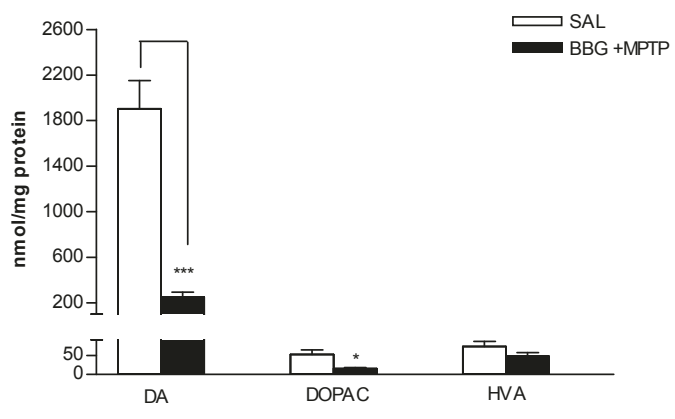

Figure 4 Effect of genetic deletion and pharmacological antagonists of P2X striatum and animal survival after in vivo MPTP treatment. Wild-type (WT) and P2X $X_{7} /-(K O)$ mice were treated with saline or with MPTP in doses indicated in the legend $(4 \times 10-20 \mathrm{mg} / \mathrm{kg}$ i. p.) and sacrificed $72 \mathrm{~h}$ later. A, B, C and E. Striatal samples were analyzed using HPLC and the amount of (A, E) dopamine (DA) 3,4-dihydroxyphenylacetic acid (DOPAC), homovanillic acid (HVA), (B) norepinephrine (NE), 3-methoxityramine (3-MT) and (C) 5-HT and 5-hydroxyindoleacetic acid (5-HIAA) is expressed in nmol/mg protein ( $\mathrm{n}=5-8)$. D. Survival curves of WT and P2X $\mathrm{X}_{7}-/-$ (KO) mice subjected to in vivo MPTP $(4 \times 20 \mathrm{mg} / \mathrm{kg}$ i.p.) treatment ( $\mathrm{n}=16 / \mathrm{group})$. E. Effect of Brilliant blue $\mathrm{G}$ (BBG, $50 \mathrm{mg} / \mathrm{kg}$ i.p.) pretreatment on the level of DA and its metabolites in the striatum of WT mice after in vivo MPTP $(4 \times 20 \mathrm{mg} / \mathrm{kg})$ treatment. BBG was injected $18 \mathrm{~h}$ before the first MPTP injection. Asterisks indicate significant differences from the corresponding saline-injected mice or between WT and KO mice as indicated $\left({ }^{*} P<0.05,{ }^{* *} P<0.01,{ }^{* * *} P<0.01\right)$. 
transcripts of the $\mathrm{P} 2 \mathrm{X}_{7}$ and $\mathrm{P} 2 \mathrm{X}_{4}$ receptor subunits were measured using real-time RT-PCR. Gene expression level was normalized to the expression level of the $18 \mathrm{~S}$ rRNA reference gene. Quantitative real-time PCR measurements revealed that the mRNA expression of the $\mathrm{P}_{2} \mathrm{X}_{7}$ receptor was up-regulated to $1.42 \pm 0.12$ of the corresponding control values (Figure 5A, $\mathrm{n}=4, \mathrm{P}<$ 0.05). In contrast, the mRNA level of the $\mathrm{P}_{2} \mathrm{X}_{4}$ receptor showed a decreasing tendency after rotenone treatment that did not reach the significance threshold (Figure 5A, $0.52 \pm 0.26$ of the corresponding control values; $n=4$, $\mathrm{P}>0.05)$.

A recent study has shown that, among the ten identified splice variants of $\mathrm{P}_{2} \mathrm{X}_{7}$ receptor subtypes, the $\mathrm{P} 2 \mathrm{X}_{7}$ (k) isoform has fully functional properties that contribute to the diversity of $\mathrm{P}_{2} \mathrm{X}_{7}$ receptor signaling in rodents [6]. We examined the mRNA expression of this splice variant using RT-PCR in control and $1 \mu \mathrm{M}$ MPTP-treated (24 h) PC12 cells and in striatal slices of WT mice with and without a $10 \mu \mathrm{M}$ in vitro rotenone pretreatment $(60 \mathrm{~min})$. We used a forward primer specific for exon 1' of the $\mathrm{P}_{2} \mathrm{X}_{7}(\mathrm{k})$ variant with a common antisense primer in exon 7 . The $\mathrm{P}_{2} \mathrm{X}_{7}(\mathrm{k})$-specific primer pairs produced amplicons in both control and rotenonetreated striatal slices but not in untreated and MPTPtreated PC12 cells (Figure 5B).

Next, we performed a quantitative identification of the expression of the $\mathrm{P}_{2} \mathrm{X}_{7}(\mathrm{k})$ variant mRNA in striatal slices of WT mice. Real-time PCR analyses revealed that the mRNA expression of the $P 2 X_{7}(\mathrm{k})$ variants was down-regulated to $0.32 \pm 0.07$ of the corresponding control values, which were established as 1 and normalized to $18 \mathrm{~S}$ reference rRNA, in response to a 60-min in vitro rotenone $(10 \mu \mathrm{M})$ pretreatment (Figure $5 \mathrm{C}, \mathrm{n}=3$, $\mathrm{P}<0.01)$.

The basal ATP levels in the substantia nigra were significantly higher, but the ADP levels were significantly lower in WT mice than in the $\mathrm{P}_{2} \mathrm{X}_{7}$-/- littermates (Figures $5 \mathrm{D}, \mathrm{E})$. When the substantia nigral preparations, which contained the cell bodies of dopaminergic neurons that project to the striatum, were preincubated in vitro with rotenone $(10 \mu \mathrm{M})$ for $60 \mathrm{~min}$, the ATP content was significantly decreased in both WT and $\mathrm{P} \mathrm{X}_{7^{-}} /$- mice (Figure 5D). The same treatment elicited a significant depletion of ATP content in the striatum of $\mathrm{P} \mathrm{X}_{7}$-/ - but not in WT mice (Figure 5D). This decrease in ATP content by rotenone was paralleled with an increase in ADP level in the substantia nigra of WT animals (Figure 5E), but similar changes were not observed in the substantia nigra of $\mathrm{P}_{2} \mathrm{X}_{7}-/$ - animals or in the striatum of either genotype (Figure 5E). AMP levels and the energy charge (EC) were not significantly altered in the substantia nigra and the striatum either by genetic deletion of $\mathrm{P}_{2} \mathrm{X}_{7}$ receptors or rotenone treatment (Figures $5 \mathrm{~F}-\mathrm{G}$ ).

Rotenone treatment depleted striatal DA content in both WT and $\mathrm{P}_{2} \mathrm{X}_{7}-/$ - mice, and the amount of DA metabolite DOPAC was significantly increased in the $\mathrm{P}_{2} \mathrm{X}_{7}-1$ - group compared to saline treatment $(P<0.05$, $P<0.01$, Figure 6A). In slices derived from $\mathrm{P}_{2} \mathrm{X}_{7}-/-$ mice, rotenone treatment also depleted the NE content $(P<0.01$, Figure $7 \mathrm{~B})$. The amounts of $3-\mathrm{MT}, 5-\mathrm{HT}$ and 5-HIAA were insignificantly changed either by rotenone treatment or by the genetic deletion of $\mathrm{P} 2 \mathrm{X}_{7}$ receptors (Figures 6B, C).

After loading striatal slices with $\left[{ }^{3} \mathrm{H}\right] \mathrm{DA}$, radioactivity uptake was $55996 \pm 9346 \mathrm{~Bq} / \mathrm{g}(\mathrm{n}=8)$ in WT mice and $71115 \pm 15573 \mathrm{~Bq} / \mathrm{g}(\mathrm{n}=4)$ in $\mathrm{P}_{2} \mathrm{X}_{7}-/$ - mice, which were not significantly different from each other $(P$ $>0.05)$. Low frequency EFS ( $25 \mathrm{~V}, 2 \mathrm{~Hz}, 240$ shocks) was used to mimic neuronal activity. This stimulation elicited a rapid and reproducible efflux of $\left[{ }^{3} \mathrm{H}\right] \mathrm{DA}$ in striatal slices obtained from the WT and $\mathrm{P}_{2} \mathrm{X}_{7}-/$ - groups (Figure 7A). Rotenone treatment did not change radioactivity uptake in the WT group $(96084 \pm 26879 \mathrm{~Bq} / \mathrm{g}$, $\mathrm{n}=4 ; P>0.05)$ and in the $\mathrm{P}^{2} \mathrm{X}_{7}-/$ - group $(42072 \pm$ $6569 \mathrm{~Bq} / \mathrm{g}, \mathrm{n}=8 ; P>0.05)$, whereas electrical field stimulation evoked $\left[{ }^{3} \mathrm{H}\right] \mathrm{DA}$ release also remained unchanged in WT and $\mathrm{P}_{2} \mathrm{X}_{7} / /$ - mice (Figure $7 \mathrm{~B}$ ). These results imply that, despite the considerable depletion of endogenous DA content, striatal slices accumulate and release exogenous dopamine after rotenone treatment in response to neuronal activity, and the genetic deletion of $\mathrm{P}_{2} \mathrm{X}_{7}$ receptors did not alter this ability of dopaminergic nerve terminals.

The levels of the excitatory amino acids, glutamate and aspartate, and of the inhibitory amino acid, GABA, in the striatum did not change following in vitro rotenone treatment and was similar in WT and $\mathrm{P}_{2} \mathrm{X}_{7}-/$ - animals (Figure $7 \mathrm{C}$ ). In contrast, the content of the endocannabinoid, 2-arachidonoyl glycerol (2-AG), but not anandamide (AEA), was markedly elevated after rotenone treatment in the WT mice (Figure 7D). Although rotenone treatment also tended to increase 2AG levels in the $\mathrm{P}_{2} \mathrm{X}_{7}-/$ - mice, the elevation was much lower than in the presence of $\mathrm{P}^{2} \mathrm{X}_{7}$ receptors (Figure 7D).

\section{Discussion}

The main objective of our study was to examine the role of the $\mathrm{P}_{2} \mathrm{X}_{7}$ receptor in various $\mathrm{PD}$ models. We demonstrated that the mRNA encoding the $\mathrm{P}_{2} \mathrm{X}_{7}$ receptor was up-regulated in animal models of PD. However, our results conflict with the concept that treatment with $\mathrm{P}_{2} \mathrm{X}_{7}$ receptor antagonists can alleviate the progress of PD. 
B

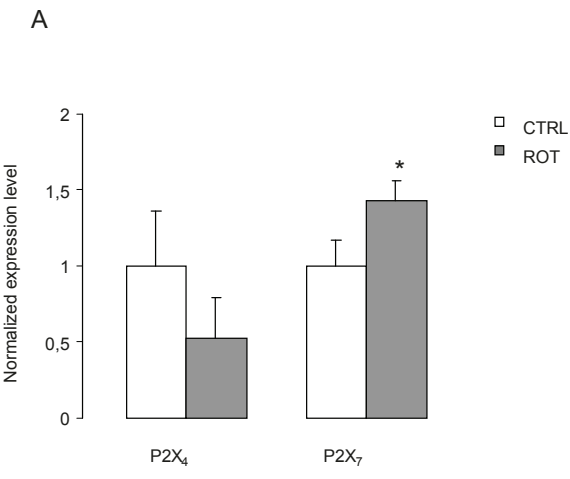

D

ATP

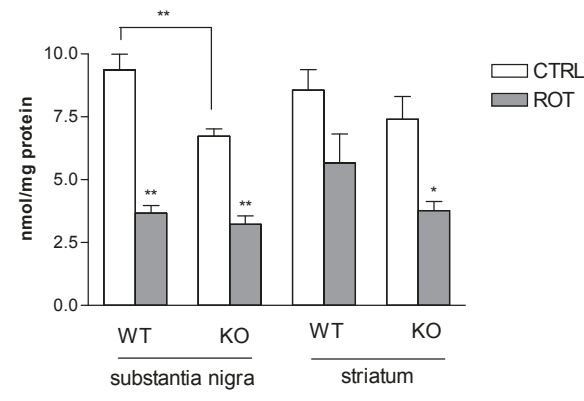

$\mathrm{F}$

AMP

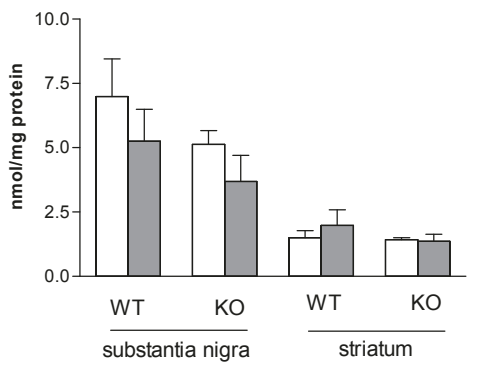

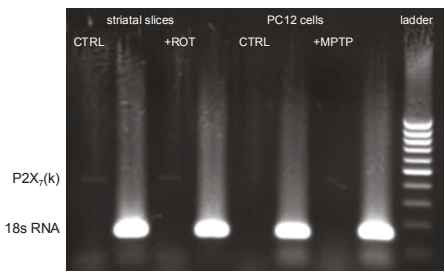

C

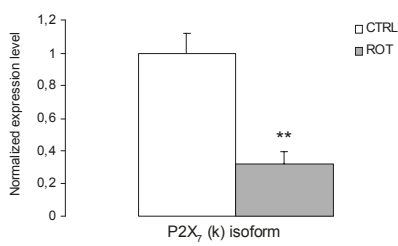

$\mathrm{E}$

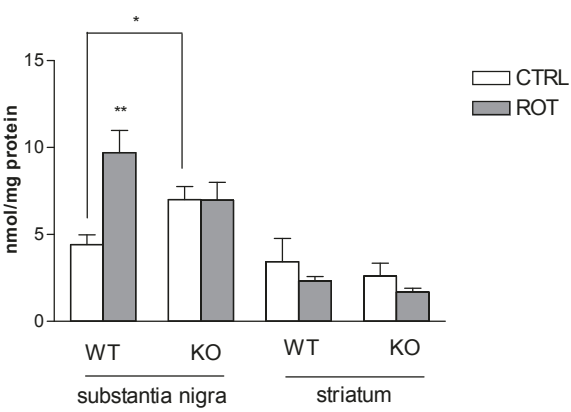

G

EC

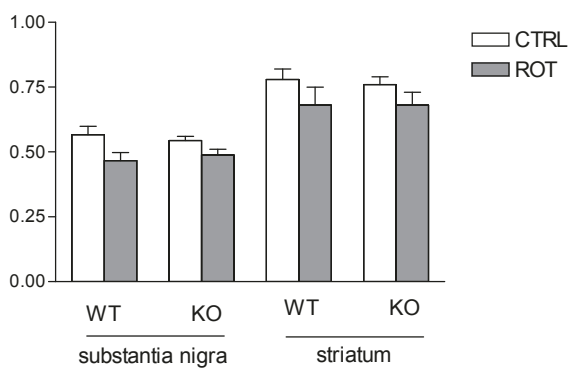

Figure 5 The effect of in vitro rotenone pretreatment on the mRNA expression of $\mathrm{P}_{2} \mathrm{X}_{7}$ and $\mathrm{P} 2 \mathrm{X}_{4}$ receptors and the $\mathrm{P} 2 \mathrm{X}_{7}(\mathrm{k}) \mathrm{splice}$ variant, ATP, ADP and AMP contents and on the energy charge in the substantia nigra and striatal slices of wild-type (WT) and P2X receptor knockout (KO) mice. Striatal slices were preincubated with in vitro rotenone (10 $\mu \mathrm{M})$ for $60 \mathrm{~min}$. (A) Quantitative SYBR Green real-time PCR was performed using specific primers. The experiments were repeated twice with similar results. The expression level of the P2X receptors was normalized to the expression level of the distinct housekeeping gene, $18 \mathrm{~S}$ rRNA. Data are displayed as the means \pm S.E.M. Asterisks indicate significant differences from the corresponding control $\left({ }^{*} P<0.05\right.$, Student's t-test). B. Confirmation of the expression of the $P 2 X_{7}(k)$ variant using RT-PCR with specific forward primers for $P 2 X_{7}(k)$ isoforms and a common reverse primer. RT-PCR analysis showed that $P 2 X_{7}(k)$-specific primer pairs produced amplicons are present in striatal slices. The gel is 1.5\%, 1× TBE buffer. A 100-bp DNA ladder (Fermentas, Vilnius, Lithuania) was used to identify PCR fragment sizes, and the amplification of 18s RNA was used as an internal control. C. Changes in mRNA expression levels of $\mathrm{P} 2 \mathrm{X}_{7}(\mathrm{k})$ variant in the striatum obtained from $\mathrm{P} 2 \mathrm{X}_{7}$ receptor wild-type mice after in vitro rotenone pretreatment. Quantitative SYBR Green realtime PCR was performed using specific primers. The experiments were repeated twice with similar results. The expression level of the P2X $X_{7}(k)$ isoform was normalized to the expression level of the distinct housekeeping gene $18 \mathrm{~S}$ rRNA. Data are displayed as the means \pm S.E.M. Asterisks indicate significant differences from the corresponding control (**P $<0.01$, Student's t-test). D, E, F. Tissue contents of ATP, ADP and AMP, expressed in $\mathrm{nmol} / \mathrm{mg}$ protein $(\mathrm{n}=5-8)$. G. For the calculation of energy charge $(\mathrm{EC})$ see Materials and Methods. ${ }^{*} P<0.05,{ }^{* *} P<0.01$, significance vs. control. 


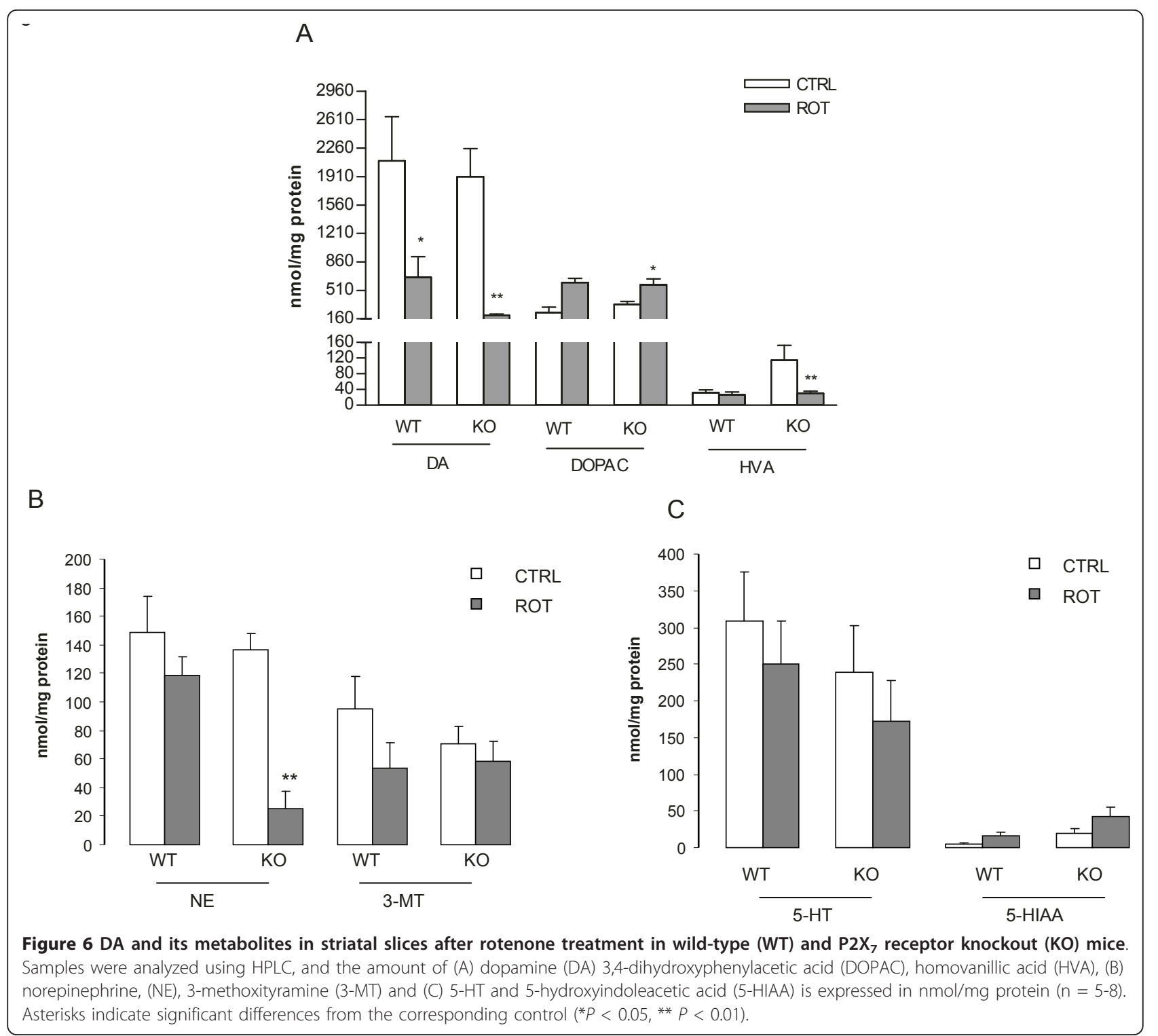

In agreement with previous studies [33-35], rotenone treatment elicited a concentration-dependent decline in cell viability of PC12 cells and primary dopaminergic neurons, as measured using the MTT and LDH assays. This effect was also obvious in morphological signs and was significantly reversed by the antiparkinsonian drug, L-deprenyl. MPTP also decreased cell viability in PC12 cells in a concentration-dependent and deprenyl-sensitive manner, as measured with the MTT assay, and caused an increase the amount or released LDH in 10 $\mu \mathrm{M}$ concentration. However, a lower concentration (1 $\mu \mathrm{M})$ of MPTP, did not elicit significant effect in PC12 cells and even increased cell viability in primary dopaminergic neurons. This latter finding is not surprising, however, because a transient proliferative effect of MPTP has been reported in PC12 cells after a $24 \mathrm{~h}$ incubation, which is dependent on the MEK1 pathway [36].

We used two $\mathrm{P} 2 \mathrm{X}_{7}$ receptor antagonists in this model, $B B G$, which is selective for $\mathrm{P}_{2} \mathrm{X}_{7}$ receptors in the concentrations used here [37], and AZ10606120, which is a potent negative allosteric modulator of $\mathrm{P}_{2} \mathrm{X}_{7}$ receptors with a nanomolar $\mathrm{IC}_{50}$ value [38]. Both compounds were found to confer protection against MPTP treatment in both MTT and LDH assays and against rotenone-induced decrease in cell viability of PC12 cells when viability was measured using the LDH assay. Because the stimulation of $\mathrm{P}_{2} \mathrm{X}_{7}$ receptors leads to cell death in different cell types [32,39], these results imply that $\mathrm{P} 2 \mathrm{X}_{7}$ receptors were endogenously activated by the released ATP, and thereby contributed to toxicity elicited by mitochondrial toxins. 


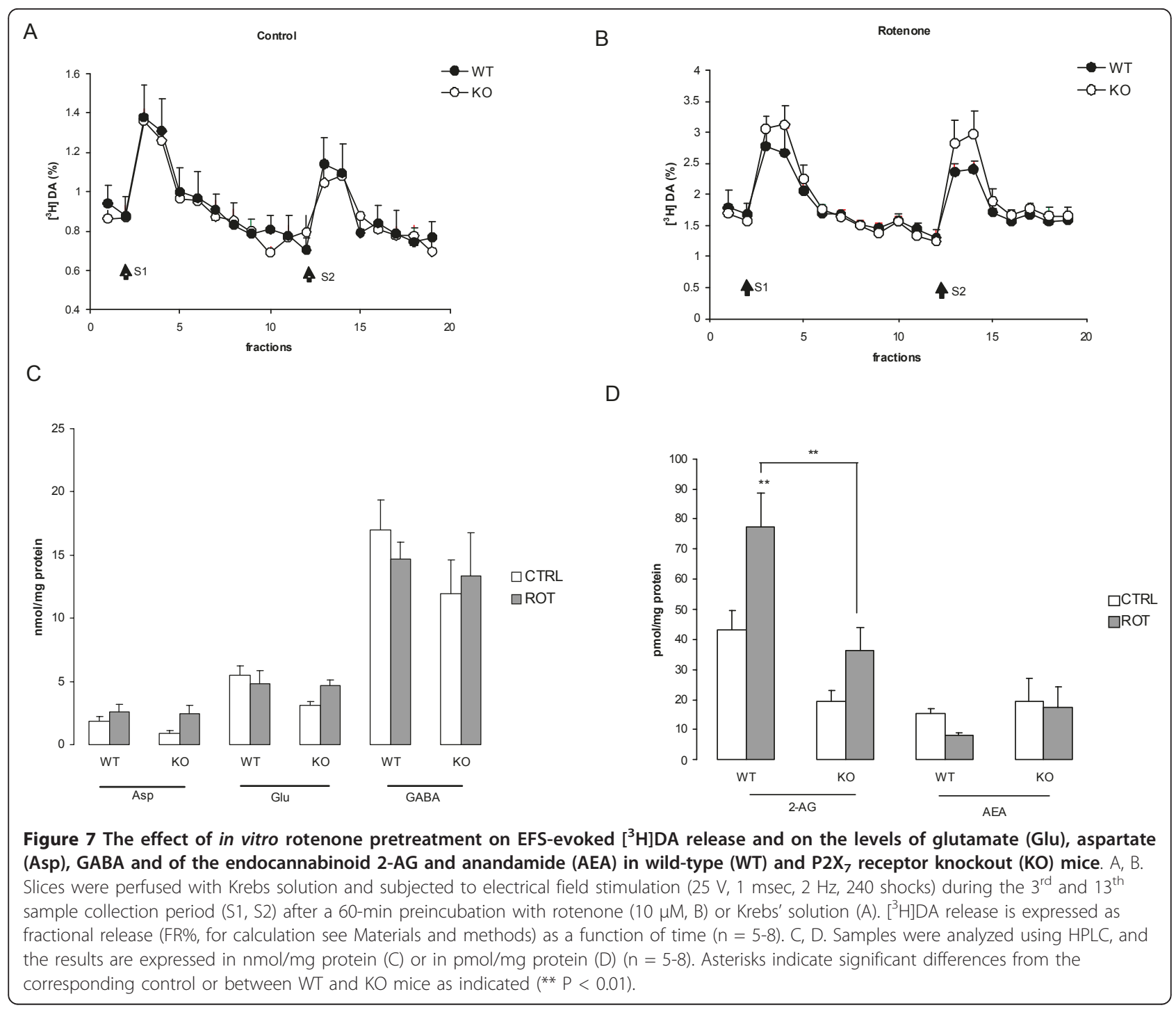

In contrast, we could not detect a protective effect against rotenone of either BBG or AZ10606120, when cell viability was measured using the MTT assay in PC12 cells, and when primary midbrain culture was assessed. PC12 is a pheochromocytoma cell line able to synthesize catecholamines, whereas primary midbrain culture is a mixed population consisting of glia and $\mathrm{MAP}^{+}$neurons, including $\mathrm{TH}^{+}$immunopositive dopaminergic neurons. Therefore, one possible explanation to the lack of protective effect of $\mathrm{P} 2 \mathrm{X}_{7}$ receptor antagonists in the primary culture is the presence of glia, which also express $\mathrm{P}_{2} \mathrm{X}_{7}$ receptors and, which might also influence the process leading to neuronal death. This assumption is supported by further observations of the present study using in vivo MPTP treatment and in vitro striatal slices. In fact we could not detect protective effect of genetic deletion of $\mathrm{P} 2 \mathrm{X} 7$ receptors in those PD models, where the synaptic organization and its environment provided by the glia was retained.

The up-regulation of $\mathrm{P} 2 \mathrm{X}_{7}$ and $\mathrm{P} 2 \mathrm{X}_{4}$ receptors at the mRNA level was also observed in the substantia nigra and striatum after the in vivo treatment with the dopaminergic neurotoxin, MPTP. To examine whether these changes were also translated to protein synthesis, we examined the distribution of $\mathrm{P}_{2} \mathrm{X}_{7}$ receptor immunoreactivity in the striatum in saline- and MPTP-treated WT mice. As expected, $\mathrm{P}_{2} \mathrm{X}_{7}$ receptor immunofluorescence was localized to microglia in the striatum of WT mice. However, no visible change in $\mathrm{P} 2 \mathrm{X}_{7}$ receptor immunostaining was observed after in vivo MPTP treatment. This result is in agreement with the findings of Amadio et al. [29], who found an unchanged $\mathrm{P} 2 \mathrm{X}_{7}$ protein level after 6-OHDA denervation in the rat striatum. Although the precise cell type specific localization of 
$\mathrm{P}_{2} \mathrm{X}_{7}$ receptors requires further investigation, these findings imply that activity-dependent changes in the level of mRNA encoding $\mathrm{P}_{2} \mathrm{X}_{7}$ receptors is not accompanied with similar changes in protein synthesis, or that they are compensated by counter-regulatory events.

When mice were pretreated in vivo with MPTP, a dose-dependent and severe depletion of endogenous DA in the striatum was observed as a consequence of the ongoing degeneration of dopaminergic nerve terminals. Although basal dopamine levels were higher in the striata of $\mathrm{P}^{2} \mathrm{X}_{7}-/$ - mice, MPTP treatment elicited a similar reduction in DA content in the WT mice. Moreover, after the genetic deletion of this receptor subtype, a reduction in NE content was also manifest at the lower dose of MPTP treatment. This result indicates an extension of neurodegeneration in the absence of $\mathrm{P}_{2} \mathrm{X}_{7}$ receptors, although endogenous 5-HT levels were relatively preserved. To test the effect of the pharmacological inhibition of $\mathrm{P}_{2} \mathrm{X}_{7}$ receptors, we utilized BBG, a $\mathrm{P} 2 \mathrm{X}_{7}$ receptor antagonist that penetrates the blood brain barrier, and is efficacious in animal models of spinal cord injury $[17,18]$ as well as Huntington's disease $[20]$ in the dose applied. Nevertheless, treatment with BBG did not afford neuroprotection in our hands, at least using an acute treatment protocol.

It has been established previously that the pathological hallmarks of PD can be reproduced in vivo with the sub-chronic application of the irreversible mitochondrial complex I inhibitor, rotenone [40-42], or with the in vitro pretreatment of striatal slices with rotenone [33] in rats. Our findings in mice confirm and extend these data, i.e., the depletion of endogenous DA levels in the striatum concomitant with a decrease in endogenous ATP levels in the striatum and substantia nigra. Interestingly, a more pronounced ATP depletion was found in the substantia nigra than in the striatum after rotenone treatment, which corroborates with the wellknown vulnerability of this brain area to mitochondrial toxins. Similar to the results seen after in vivo MPTP treatment however, genetic deletion of $\mathrm{P}_{2} \mathrm{X}_{7}$ receptors did not reverse these changes but exacerbated the damage and elicited a further drop of endogenous ATP and NE contents. Moreover, basal ATP levels were substantially lower in the substantia nigra of $\mathrm{P}_{2} \mathrm{X}_{7} / /$ - mice. Taken together, $\mathrm{P}_{2} \mathrm{X}_{7}$ receptor deficiency did not ameliorate the effects of dopaminergic neurotoxins, rather these effects were potentiated.

Although these findings are somewhat unexpected in light of the regulation of excitotoxic and neuroinflammatory pathways by $\mathrm{P}_{2} \mathrm{X}_{7}$ receptors $[2,3,43,44]$, there are several explanations for the lack of neuroprotection following genetic deletion and pharmacological antagonism of $\mathrm{P}_{2} \mathrm{X}_{7}$ receptors.
It is well known that results generated using knockout mice must be treated with caution because compensatory mechanisms may occur. Our results clearly demonstrated that mRNA encoding the $\mathrm{P}_{2} \mathrm{X}_{4}$ receptor was up-regulated in the striatum of $\mathrm{P}^{2} \mathrm{X}_{7}-/$ - mice compared to the WT group, and the expression levels of the $\mathrm{P}_{2} \mathrm{X}_{7}$ and $\mathrm{P}_{2} \mathrm{X}_{4}$ receptors were similarly elevated after MPTP treatment in PC12 cells. However, a similar change in $\mathrm{P}_{2} \mathrm{X}_{4}$ mRNA level was not observed in the rotenone-treated striatum. $\mathrm{P}_{2} \mathrm{X}_{4}$ and $\mathrm{P} 2 \mathrm{X}_{7}$ receptors are frequently co-expressed [4] in particular on microglia, which is the cell type that governs neuroinflammation. Weinhold et al. [45] found that in alveolar epithelial cells, the expression of $\mathrm{P}^{2} \mathrm{X}_{4}$ receptors was strongly increased after $\mathrm{P}_{2} \mathrm{X}_{7}$ down-regulation, which indicates crosstalk and feedback signaling between these two receptors. Taking into account that the affinity of ATP for $\mathrm{P}_{2} \mathrm{X}_{4}$ receptors is much higher than for $\mathrm{P}_{2} \mathrm{X}_{7}$ receptors [5], the $\mathrm{P}_{2} \mathrm{X}_{4}$ receptor is a strong candidate to compensate the actions mediated by $\mathrm{P} 2 \mathrm{X}_{7}$ receptors in cases of genetic deletion or pharmacological blockade.

Another possible interpretation of the lack of neuroprotection following the deletion of $\mathrm{P}_{2} \mathrm{X}_{7}$ receptors is the existence of splice variants, which partly retain their functionality in the CNS in different $\mathrm{P}_{2} \mathrm{X}_{7}$ knockout mice lines [6]. So far ten splice variants of the $\mathrm{P}_{2} \mathrm{X}_{7}$ receptor $\left(\mathrm{P}_{2} \mathrm{X}_{7}(\mathrm{~b})\right.$ through $\left.\mathrm{P} 2 \mathrm{X}_{7}(\mathrm{k})\right)$ have been described $[6,46,47]$. However, out of them only one, the recently identified $\mathrm{P}_{2} \mathrm{X}_{7}(\mathrm{k})$ [6] has been found to be fully functional. Therefore, we have examined the mRNA expression of this variant in PC12 cells and in the rotenone treated rat striatum. The transcript encoding the $\mathrm{P}_{2} \mathrm{X}_{7}$ (k) variant was expressed in the WT striatum, but its expression level was decreased after rotenone treatment, which does not support its involvement as a compensatory receptor.

A third, most intriguing possibility is that that activation of $\mathrm{P}_{2} \mathrm{X}_{7}$ receptors may also mediate neuroprotective effects, which could counterbalance its deleterious actions. The activation of $\mathrm{P}_{2} \mathrm{X}_{7}$ receptors in astrocytes enhances $\mathrm{P}_{2} \mathrm{Y}_{2}$ mRNA expression [48], which can trigger neuroprotective pathways through the induction of genes for anti-apoptotic factors, neurotrophins, growth factors and neuropeptides [49]. Moreover, recent studies have shown that the $\mathrm{P}_{2} \mathrm{X}_{7}$ nucleotide receptor is coupled to GSK-3 inhibition and confers neuroprotection in cerebellar granule neurons $[50,51]$. P2X 7 receptors also play important roles in the synthesis and subsequent release of endocannabinoids from activated microglia and astrocytes $[15,16]$. The activation of CB1 and $\mathrm{CB} 2$ receptors by endocannabinoids mediates neuroprotection in different pathological models [52-54], including animal models of PD $[55,56]$. Our data 
indicate that this endogenous protective mechanism was activated after an in vitro rotenone treatment because an increased level of 2-AG was detected in the striatum. In contrast, elevation of 2-AG levels was absent in the striatum of $\mathrm{P}^{2} \mathrm{X}_{7}-/$ - mice, which may lead to the alleviation of the 2-AG-mediated neuroprotective action.

Finally, an important factor that might influence whether beneficial or deleterious actions mediated by $\mathrm{P}_{2} \mathrm{X}_{7}$ receptors predominate, is the age of animals. In support of this idea, Jimenez et al. [57] found that at early ages (4-6 months), activated microglia are restricted to amyloid deposits and are characterized by the absence of cytotoxic factors using a transgenic mouse model of Alzheimer's disease. In contrast, at older ages, microglial activation shows a classic phenotype with the production of cytotoxic factors. Taking into account the governing role of $\mathrm{P}_{2} \mathrm{X}_{7}$ receptors in the activation and proliferation of microglia and in microglia-mediated death of neurons $[2,12]$, the relatively young age of the mice used in our experiments may also explain the lack of protection by $\mathrm{P}^{2} \mathrm{X}_{7}$ inhibition.

\section{Conclusions}

The results of experiments in different PD models do not indicate a consistent protective effect of deficiency or inhibition of the purinergic receptor subtype $\mathrm{P} 2 \mathrm{X}_{7}$. Moreover, certain neurochemical alterations characteristic to PD were exacerbated after MPTP or rotenone treatment in $\mathrm{P}_{2} \mathrm{X}_{7}$ deficient mice, with a concomitant decline in the accumulation of the neuroprotective endocannabinoid 2-AG. We conclude that $\mathrm{P}_{2} \mathrm{X}_{7}$ receptor deficiency or inhibition does not promote the survival of dopaminergic neurons in an in vivo or in vitro models of $\mathrm{PD}$ and supports the view that $\mathrm{P} 2 \mathrm{X}_{7}$ receptors play a double-faced role in different cellular cascades that lead to neuronal death.

\section{Methods}

\section{Animals}

All studies were conducted in accordance with the principles and procedures outlined in the NIH Guide for the Care and Use of Laboratory animals and were approved by the local Animal Care Committee of the Institute of Experimental Medicine (Budapest, Hungary, ref. No. $22.1 / 3671 / 003 / 2008)$. Two to 3-month old male wildtype (WT) and $\mathrm{P}_{2} \mathrm{X}_{7}$ receptor knockout mice $\left(\mathrm{P}^{2} \mathrm{X}_{7}-/-\right)$ were housed in a light- (12 h on, $12 \mathrm{~h}$ off) and temperature-controlled room with food and water available $a d$ libitum. All experiments were performed during the light phase between 7:30 am and 3:30 pm. Homozygous $\mathrm{P}_{2} \mathrm{X}_{7}$ receptor WT mice were bred on a background of $\mathrm{C} 57 \mathrm{Bl} / 6 \mathrm{~J}$. The original breeding pairs of $\mathrm{P} 2 \mathrm{X}_{7} \mathrm{R}-/-$ mice were kindly supplied by Christopher Gabel from Pfizer, Inc. (Groton CT, USA). The animals contained the
DNA construct P2X $\mathrm{X}_{7}$-F1 (5'-CGGCGTGCGTTTTGACATCCT-3') and P2X 7 -R2 (5'-AGGGCCCTGCGGTTCTC-3'), previously shown to delete the $\mathrm{P}_{2} \mathrm{X}_{7}$ receptor [58]. Genomic DNA was isolated from the tails of WT and $\mathrm{P}_{2} \mathrm{X}_{7}-/-$ animals, and the genotypes were confirmed by PCR analysis. Animals were randomly assigned to experimental clusters of 6-8 mice in each group. All animals were given intraperitoneal (i.p.) injections of sterile saline $(0.9 \% \mathrm{NaCl})$ or $4 \times 10-20 \mathrm{mg} / \mathrm{kg}$ MPTP, separated by $2 \mathrm{~h}$. Treatment with the P2X receptor antagonist, Brilliant blue G (BBG, $50 \mathrm{mg} / \mathrm{kg}$ i. $\mathrm{p})$, was administered $18 \mathrm{~h}$ before the first MPTP injection. Mice were euthanized by decapitation $72 \mathrm{~h}$ after the last treatment. The striatum was collected, frozen on dry ice and stored at $-70^{\circ} \mathrm{C}$ until homogenization. Other mice were treated in vitro. After decapitation, the striatum was removed and sliced into 400 - $\mu \mathrm{m}$-thick sections, and the slices were incubated with $10 \mu \mathrm{M}$ rotenone for $60 \mathrm{~min}$ in Krebs' solution kept at $37^{\circ} \mathrm{C}$ and bubbled with a mixture of $95 \% \mathrm{O}_{2}+5 \% \mathrm{CO}_{2}$ (see below).

\section{Cell culture}

PC12 cells

PC12 cells were grown in Dulbecco's Modified Eagle's Medium supplemented with $10 \%$ heat-inactivated fetal bovine serum. The cultures were maintained in a humidified atmosphere containing $5 \% \mathrm{CO}_{2}$ at $37^{\circ} \mathrm{C}$. For experiments assessing the effect of drugs on rotenoneor MPTP-induced cell death, PC12 cells were seeded on 96-well plates in a density of 5000 cells/well, preincubated with 10 and $100 \mathrm{nM}$ of L-deprenyl, AZ10606120 or BBG for $1 \mathrm{~h}$ and then treated with rotenone (0.01-30 $\mu \mathrm{M})$ or MPTP $(0.01-30 \mu \mathrm{M})$. The incubation was then continued for $20 \mathrm{~h}$ at $37^{\circ} \mathrm{C}$.

\section{Cultures of ventral midbrain cells}

Timed pregnant C57BL/6 mice were deeply anesthetized with an i.p injection of a xylazine-ketamine mixture on days 12-13.5 after vaginal plug identification. The embryos (E12 - E13.5) were aseptically dissected and rinsed with a $\mathrm{Ca}^{2+}$-free PBS ( $\left.\mathrm{pH} 7.4\right)$ containing $40 \mu \mathrm{g} /$ $\mathrm{ml}$ gentamicin (Sanofi-Aventis) and $250 \mu \mathrm{g} / \mathrm{ml}$ fungizone (Sigma, Hungary). The brains were rapidly removed and the ventral mesencephali were dissected. Tissue pieces were incubated in a trypsin solution $(0.5 \%$ trypsin (w/v; Sigma, Hungary) in PBS containing $50 \mu \mathrm{g} /$ ml DNAse I (Sigma, Hungary) for $20 \mathrm{~min}$ at room temperature. After incubation, the tissue pieces were transferred onto a nylon mesh (pore diameter $43 \mu \mathrm{m}$ ) fixed to the bottom of a polypropylene tube and triturated within the tube in 10\% FCS in Minimum Essential Medium (MEM-FCS) (Sigma, Hungary) using a Pasteur pipette. The suspension of single cells streamed through the mesh was collected (approx. $2 \mathrm{ml} / \mathrm{embryo}$ ). After 
counting in a Bürker chamber, the cells were plated in MEM-FCS onto poly-L-lysine coated 96-well culture plates (105 cells/100 $\mu \mathrm{l} /$ well; Falcon; BD) or onto polyL-lysine coated glass cover slips $(\mathrm{d}=12 \mathrm{~mm} ; 5 \times 105 /$ $500 \mu \mathrm{l} /$ well) in 4-well plates. After adhesion of cells, the medium was changed and the cells were maintained in DMEM/F12 (1/1) supplemented with B27 (Invitrogen). The medium was changed every second day and was supplemented with $20 \mathrm{ng} / \mathrm{ml} \mathrm{BDNF}$ (Invitrogen) from the second day. Cultures were treated on days 6-7 in vitro with L-deprenyl, AZ10606120 or BBG and then with $1 \mu \mathrm{M}$ rotenone or $1 \mu \mathrm{M}$ MPTP as described above.

\section{Quantitative real-time PCR experiments}

The striata and the PC12 cells were lysed and homogenized in Trizol. Total RNA was isolated from the cell lysates using the RNeasy Lipid Tissue Mini Kit (Qiagen) according to the manufacturer's instructions. The purified RNA was reverse-transcribed with a RevertAid First Strand cDNA Synthesis Kit (Fermentas, Vilnius, Lithuania) as described in our previous study [59]. Briefly, the cDNA samples were prepared by reverse transcribing 2 $\mu \mathrm{g}$ of total RNA using $1 \mu \mathrm{l}$ of RevertAid H Minus MMuLV reverse transcriptase in a mixture containing $5 \mu \mathrm{l}$ of $5 \times$ reaction buffer, $1 \mu$ l random hexamer primer $(10$ $\mathrm{pmol} / \mu \mathrm{l}), 1 \mu \mathrm{l}$ of RiboLock ${ }^{\mathrm{TM}}$ RNase Inhibitor $(20 \mathrm{u} / \mu \mathrm{l})$ and $2 \mu \mathrm{l}$ of $10 \mathrm{mM}$ dNTP mix, which was brought up to a final volume of $20 \mu \mathrm{l}$ with $0.1 \%$ diethylpyrocarbonate-treated distilled water. The reverse-transcription reaction was performed at $70^{\circ} \mathrm{C}$ for $5 \mathrm{~min}$ and was followed by incubation at $25^{\circ} \mathrm{C}$ for $5 \mathrm{~min}$. The synthesis was continued for $10 \mathrm{~min}$ at $25^{\circ} \mathrm{C}$ and was followed by $60 \mathrm{~min}$ at $42^{\circ} \mathrm{C}$. The samples were finally stored at $-20^{\circ}$ $\mathrm{C}$. The expression levels of the target genes were determined from the cDNA samples using quantitative realtime PCR (Rotor-Gene 3000; Corbett Research, Sydney, Australia). Real-time PCR was performed according to standard protocols using the LightCycler DNA Master SYBR Green I Kit (Roche, Indianapolis, IN, USA). PCR conditions were optimized for primers, templates and $\mathrm{MgCl}_{2}$. The PCR cycling protocol was set to the following parameters: initial denaturation, $95^{\circ} \mathrm{C}$ for $10 \mathrm{~min}$; cycling, $95^{\circ} \mathrm{C}$ for $20 \mathrm{~s}, 59^{\circ} \mathrm{C}$ for $20 \mathrm{~s}, 72^{\circ} \mathrm{C}$ for $20 \mathrm{~s} ; 45$ cycles. All PCR primers were based on a previous study [60] with the following sequences: $\mathrm{P}_{2} \mathrm{X}_{4}$ receptor forward: 5'-ATC GTC ACC GTG AAC CAG ACA CA, reverse: 3'-CCA CGA TTG TGC CAA GAC GGA AT P2X $\mathrm{X}_{7}$ receptor forward: 5'-CCA CAA CTA CAC CAC GAG AAA C, reverse: 3'-ACT TCT TGG CCC TTG ACA TCT T; $18 \mathrm{~S}$ forward: 5'-GTA ACC CGT TGA ACC CCA TT, reverse: 3'-CCA TCC AAT CGG TAG TAG CG. Primers for the amplification of the $\mathrm{P}_{2} \mathrm{X}_{7}(\mathrm{k})$ variant cDNAs were based on the study of Nicke et al. [6] and were the following: $\mathrm{P} 2 \mathrm{X}_{7}$ receptor 1' exon- specific forward primer 5' GCC CGT GAG CCA CTT ATG C-3' and reverse primer in exon 7 5'-TCT GTA AAG TTC TCT CCT GC-3'. The conditions for amplification in this case were as follows: $95^{\circ} \mathrm{C}$ for $10 \mathrm{~min}$, initial denaturation at $94^{\circ} \mathrm{C}$ for $30 \mathrm{~s}, 59^{\circ} \mathrm{C}$ for $30 \mathrm{~s}$, and $72^{\circ} \mathrm{C}$ for $30 \mathrm{~s}$ for 45 cycles with a final extension at $72^{\circ} \mathrm{C}$ for $7 \mathrm{~min}$. To ensure the specificity of the reaction and accurate quantification, a melting curve analysis was performed after each reaction, which confirmed the lack of primer-dimer artifacts or contamination in all cases. All $\Delta \mathrm{Ct}$ values were calculated using the Rotor-Gene 6 software (Corbett Research, Sydney, Australia). Expression levels of the target genes were normalized to the reference gene, $18 \mathrm{~S}$ rRNA. The target gene and the reference gene were measured together within the same experiment. To compare the expression levels of target genes between different experimental groups, the efficiency calibrated model of Pfaffl [61] was applied. Differences in gene expression were considered significant when the $P$ level was $<0.05$. Data are presented as the mean normalized expression ratio \pm SEM.

\section{RT-PCR amplification of $\mathrm{P}_{2} \mathrm{X}_{7}(\mathrm{k})$ variant mRNAs}

The striata and the PC12 cells were lysed and homogenized in Trizol. Total RNA samples were isolated and purified from the cell lysates using the RNeasy Lipid Tissue Mini Kit (Qiagen) according to the manufacturer's instructions. RNA $(2 \mu \mathrm{l})$ was reverse-transcribed with the RevertAid First Strand cDNA Synthesis Kit (Fermentas, Vilnius, Lithuania) as described in our previous study [59]. Primers for amplification of the $\mathrm{P}^{2} \mathrm{X}_{7}$ (k) variant cDNAs were subjected to RT-PCR amplification under the following conditions: 35 cycles, initial denaturation at $94^{\circ} \mathrm{C}$ for $30 \mathrm{~s}, 59^{\circ} \mathrm{C}$ for $30 \mathrm{~s}$, and $72^{\circ} \mathrm{C}$ for $30 \mathrm{~s}$ for 35 cycles with a final extension at $72^{\circ} \mathrm{C}$ for 7 min.

\section{Fluorescence microscopy}

Primary cultures grown on microscopic cover slips for 8 days were rinsed with PBS and fixed in $4 \%$ paraformaldehyde ( $\mathrm{w} / \mathrm{v}$ in PBS) for $40 \mathrm{~min}$ at room temperature. After washing with PBS, the cultures were treated with $0.1 \%$ TritonX100 in PBS for $5 \mathrm{~min}$ and non-specific binding sites were blocked by a 2-hour incubation with $3 \%$ donkey and normal horse sera (Jackson ImmunoResearch Europe Ltd. Newmarket, Suffolk, UK) in $0.1 \mathrm{M}$ phosphate buffer (PB, pH 7.4). Cells were incubated with a mixture of MAP2 (1:1000; polyclonal rabbit; Abcam, Cambridge, UK) and tyrosine hydroxylase (1:500; monoclonal mouse; Chemicon, Billerica, MA, USA) primary antibodies at $4^{\circ} \mathrm{C}$ overnight. For control experiments, the primary antibodies were omitted. Biotinylated anti-mouse IgG (Vector Laboratories; Burlingame, CA, USA) and Alexa Fluor 594-conjugated anti- 
rabbit IgG (Molecular Probes/Invitrogen) (1:1000) were applied as secondary antibodies for $2 \mathrm{~h}$ at room temperature. Streptavidin-FITC $(1: 1000)$ in PB was applied for $2 \mathrm{~h}$. Stained cultures were mounted in Mowiol 4-88 (Polysciensce Inc, Warrington, PA, US) containing Hoechst nuclear dye and investigated with an Axiovert $200 \mathrm{M}$ microscope and the AxioVision 4.8 program (Zeiss, Jena Germany).

\section{Laser scanning confocal microscopy for the investigation of $\mathrm{P}_{2} \mathrm{X}_{7}$ receptor localization in striatal sections}

After removing the brain, the striatum was removed and fixed for $2 \times 1 \mathrm{~h}$ in $4 \%$ paraformaldehyde in $0.1 \mathrm{M}$ phosphate-buffered saline ( $\mathrm{pH}$ 7.4). Thirty-micron sections were cut using a vibrating microtome (VT1000S; Leica Microsystems, Milton Keynes, UK). The sections were washed, kept in $0.1 \mathrm{M}$ phosphate-buffered saline and then transferred to $30 \%$ sucrose in PBS at $4{ }^{\circ} \mathrm{C}$ until they sank. Freeze-thawing in liquid nitrogen was applied to increase the penetration of the antisera used for immunostaining. The sections were incubated first in the mixture of 3-3\% donkey and normal horse sera (Jackson ImmunoResearch Europe Ltd. Newmarket, Suffolk, UK) in $0.1 \mathrm{M}$ phosphate buffer $\mathrm{pH} 7.4$ for $2 \mathrm{~h}$, and then in the 1:200 dilution of the $\mathrm{P}_{2} \mathrm{X}_{7}$ polyclonal antibody (Santa Cruz Biotechnology, Inc. Santa Cruz, CA, USA) overnight at $4^{\circ} \mathrm{C}$. After thorough washing, fluorescein-labeled GSL I - isolectin B4 (Vector Laboratories; Burlingame, CA, USA) in a 1:100 dilution and 1:400 DyLight 549 AffiniPure Donkey Anti-Goat IgG (Jackson ImmunoResearch) were applied overnight. Sections incubated without primary antibodies served as controls. After final washes in PBS, the sections were transferred onto microscopic slides and mounted in Vectashield (Vector Laboratories; Burlingame, CA, USA). Confocal microscopic images were scanned with a Nikon A1R microscope equipped with NIS-Elements $\mathrm{C}$ software. Images were edited and the brightness and contrast were adjusted if necessary using Adobe Photoshop CS3 (San Jose, CA, USA).

\section{Cell viability assays}

Cell viability was assessed using the colorimetric reagent, 3-[4,5-dimethylthiazol-2-yl]-2,5-diphenyl tetrazolium bromide (MTT). A stock solution of the dye was prepared, filter-sterilized and stored at $-20^{\circ} \mathrm{C}$. After MPTP or rotenone treatment in 96-well plates, $5 \mathrm{mg} / \mathrm{ml}$ MTT was added to each well, and the incubation was continued for another $4 \mathrm{~h}$. The converted dye was solubilized with acidic isopropanol $(0.04 \mathrm{M} \mathrm{HCl}$ in absolute isopropanol). Reduced MTT was measured at a wavelength of $570 \mathrm{~nm}$.

As another indicator of cell viability, lactate dehydrogenase (LDH, E.C. 1.1.1.27) was also assayed in experiments performed on PC12 cells. LDH activity that had been released into the media was evaluated using the CytoTox96 nonradioactive assay kit (Promega, Madison, WI, USA) according to the manufacturer's instructions. The LDH activity was quantified by measuring the wavelength absorbance at $490 \mathrm{~nm}$ with a Perkin-Elmer 1420 Multilabel counter. The released LDH activity is expressed as a percentage of total LDH activity, which was determined after freeze-thaw lysing of the cells.

HPLC determination of adenine nucleotides, monoamines, amino acids and endocannabinoids

Animals were sacrificed by decapitation, and the striatum or the substantia nigra was dissected on ice under a stereomicroscope. In the case of in vivo MPTP-treated animals, after the preparation of the striatum, the native tissue was frozen in liquid nitrogen. In the other experiments, striatal slices or substantia nigra preparations were frozen after a $1 \mathrm{~h}$ in vitro pre-incubation with rotenone $(10 \mu \mathrm{M})$. The weighed frozen tissue was homogenized in an appropriate volume of ice-cold $0.1 \mathrm{M}$ perchloric acid that contained theophylline (as an internal standard) in a $10 \mathrm{nmol} / \mathrm{ml}$ concentration and 0.5 $\mathrm{mM}$ sodium metabisulfite (antioxidant for biogenic amines). The suspension was centrifuged at $300 \mathrm{~g}$ (4500 $\mathrm{rpm}$ ) for $10 \mathrm{~min}$ at $0-4^{\circ} \mathrm{C}$. The excess perchlorate anion in the supernatant was removed by the addition of $2 \mathrm{M}$ $\mathrm{KOH}$ in 7:3 ratios, respectively. The potassium perchlorate was removed by centrifugation as described above. The supernatant was kept at $-20^{\circ} \mathrm{C}$ until analyzed. The pellet was saved for protein measurement according to Lowry et al. [62].

A Gilson liquid chromatographic System with 715operation software (Gilson Medical Electronics Inc., Middletown, WI, USA) was used. Two delivery pumps (Model 305) and a programmable auto injector (Model $231 \mathrm{XL}$ ) were built in. The system was equipped with BAS CC- 4 amperometric and Agilent 1100 variable wavelength detectors in a cascade line. For sample cleaning, a "trap-column" (15-25 $\mu \mathrm{m}$ Nucleosil C-18 (20 $\times 4.0)$ ) was inserted into a loop position. The separations were performed on a $3 \mu \mathrm{m}$ Discovery C18 HS (150 $\times 4.0 \mathrm{~mm}$ ) analytical column. For the quantification of nucleotides and biogenic amines, a two-dimensional reversed-phase and an ion pair chromatographic separation were used [40]. After the elution of nucleotides, an ion pair-reversed-phase buffer at constant flow rate $(0.8$ $\mathrm{ml} / \mathrm{min}$ ) was applied from the 11th to 55 th min of analysis. The detection of adenine nucleotides and internal standards (IS) was performed at $254 \mathrm{~nm}$ wavelengths by $\mathrm{UV}$, and the biogenic amines were measured at a $0.73 \mathrm{~V}$ potential of electrochemical detection. The retention order of UV-detected compounds were as follows: 
adenosine 5'-triphosphate (ATP) $3.6 \mathrm{~min}$, adenosine 5'diphosphate (ADP) $6.1 \mathrm{~min}$, adenosine 5'-monophosphate (AMP) $11.7 \mathrm{~min}$ and theophylline (IS) $21.2 \mathrm{~min}$. The order of monoamines were norepinephrine (NE) 14.7 min, 3,4-dihydroxyphenylacetic acid (DOPAC) 16.8 min, 5-hydroxy indolacetic acid (5-HIAA) $19.3 \mathrm{~min}$, dopamine (DA) $25.5 \mathrm{~min}$, homovanillic acid (HVA) 26.8 min, 3-methoxytyramine (3-MT) $31.2 \mathrm{~min}$ and 5-hydroxytryptamine (5-HT) $39.3 \mathrm{~min}$.

The separation of pre-column dansylated amino acids and endocannabinoids was performed with a gradient elution-working mode at ambient temperature. The mobile phase A consisted of 5/95 (v/v) 78/22 acetonitrile/methanol in $15 \mathrm{mM}$ ammonium formate buffer, and the mobile phase B was composed of 90/10 (v/v 78/ 22) acetonitrile/methanol in ammonium formate buffer, $\mathrm{pH}$ 3.7. The mobile phase $\mathrm{B}$ increased linearly (at 0.11 $\min$ to $50 \%$ at $17 \mathrm{~min} 72 \%$ and at $26 \mathrm{~min} 100 \%$ and was run to $54 \mathrm{~min}$ ), and the flow rate was $0.7 \mathrm{ml} / \mathrm{min}$. The analytical and the trap column were equilibrated for 10 min, and the enrichment and clean-up procedures were started. Dansylated derivatives were detected using an absorbance detector (Agilent 1100) at a $319 \mathrm{~nm}$ wavelength. The retention times of dansylated compounds were as follows: aspartic acid (Asp) $10.3 \mathrm{~min}$, glutamic acid (Glu) $11.4 \mathrm{~min}$, gamma amino butyric acid (GABA) $16.2 \mathrm{~min}$, AEA $48.5 \mathrm{~min}$ and 2-AG $50.5 \mathrm{~min}$. Pre-column derivatization was performed by mixing $50 \mu \mathrm{l}$ of dansyl chloride (prepared by dissolving $5 \mathrm{mg} 5$ (dimethylamino)naphthalene-1-sulfonyl chloride in acetonitrile daily and adding $50 \mu \mathrm{l}$ of $2 \mathrm{M}$ sodium carbonate, which contained norvaline as an internal standard in 20 $\mu \mathrm{M}$ with $25 \mu \mathrm{l}$ of sample. After a 10 -min reaction time at $60^{\circ} \mathrm{C}$, the mixture was acidified with $25 \mu \mathrm{l}$ of $6 \mathrm{M}$ formic acid and injected onto the "trap-column".

The concentrations of separated compounds were calculated using a two-point calibration curve internal standard method: $(\mathrm{Ai} * \mathrm{f} * \mathrm{~B}) /(\mathrm{C} * \mathrm{Di} * \mathrm{E})$ (Ai: Area of component; B: Sample volume; C: Injection volume; Di: Response factor of 1 pmol of standard; E: Protein content of sample; f: factor of Internal Standard (IS area in calibration/IS area in actual)). The data are expressed as nmol per mg protein or as pmol per mg protein.

\section{$\left[{ }^{3} \mathrm{H}\right]$ Dopamine release experiments}

Mice were decapitated and the brain was quickly removed into an ice-cold Krebs' solution. The striatum was dissected out and sliced into 400- $\mu$ m-thick sections with a McIlwain tissue chopper. The release experiments were performed as described previously [33,41]. Briefly, the slices were pretreated with rotenone (10 $\mu \mathrm{M})$ for $60 \mathrm{~min}$ and then rinsed with a normal Krebs' solution. The slices were then incubated in $1 \mathrm{ml}$ of Krebs' solution containing $5 \mu \mathrm{Ci}\left[{ }^{3} \mathrm{H}\right] \mathrm{DA}$ for $45 \mathrm{~min}$, during which they were continuously gassed with a mixture of $95 \% \mathrm{O}_{2}$ and $5 \% \mathrm{CO}_{2}$ at $37^{\circ} \mathrm{C}$. After incubation, the slices were rinsed and transferred to tissue chambers and perfused continuously with a modified Krebs solution (in mM: $\mathrm{NaCl} 113, \mathrm{KCl} 4.7, \mathrm{CaCl}_{2} 2.5, \mathrm{KH}_{2} \mathrm{PO}_{4}$ 1.2, $\mathrm{MgSO}_{4} 1.2, \mathrm{NaHCO}_{3} 25, \mathrm{Na}_{2}$ EDTA 0.03 , ascorbic acid 0.3 , and glucose 11.5 ) at a rate of $0.7 \mathrm{ml} / \mathrm{min}$. After a 60-min pre-perfusion, 3-min samples were collected and assayed for $\left[{ }^{3} \mathrm{H}\right] \mathrm{DA}$.

Electrical field stimulation (EFS, S1, S2) was delivered by a Grass S88 stimulator twice, during the $3^{\text {rd }}$ and $13^{\text {th }}$ sample of the collection period, using platinum ring electrodes attached to the top and bottom of tissue chambers with the following parameters: $25 \mathrm{~V}, 1 \mathrm{msec}$, $2 \mathrm{~Hz}, 240$ shocks. At the end of the experiment, the slices were homogenized in $0.5 \mathrm{ml}$ of $10 \%$ trichloroacetic acid. A $0.5 \mathrm{ml}$ aliquot of the superfusate and $0.1 \mathrm{ml}$ of the tissue supernatant were added to $2 \mathrm{ml}$ of scintillation cocktail (Ultima Gold, Packard). Tritium was measured with a Packard 1900 TR liquid scintillation counter using an internal standard and expressed as percentage of the amount of radioactivity in the tissue at the time of sample collection (fractional release, FR \%). The tissue tritium uptake was determined as the sum release + the tissue content after the experiment and expressed in $\mathrm{Bq} / \mathrm{g}$.

\section{Materials}

The following materials were used: brilliant blue $G$ (BBG), L-deprenyl, DMSO, Dulbecco's Modified Eagle's Medium, fetal bovine serum, 1-methyl-4-phenyl-1,2,3,6tetrahydropyridine (MPTP), rotenone, 3-[4,5dimethylthiazol-2-yl]-2,5-diphenyl tetrazolium bromide (MTT), (all from Sigma-Aldrich, St. Louis, MO), AZ10606120 dihydrochloride (Tocris Bioscience, Ellisville, MO, USA). All solutions were freshly prepared on the day of use.

\section{Data analysis}

All data are expressed as means \pm S.E.M. of $n$ observations. Statistical analyses were performed using an ANOVA followed by the Dunnett test (multiple comparisons) or Student's t-test (pair-wise comparisons). The log-rank test was used for the statistical evaluation of survival data. Graphpad Prism software was used for all statistical analyses. P values of less than 0.05 were considered statistically significant.

Adenylate energy charge (EC), introduced by Atkinson [63], was calculated accordingly:

$$
\mathrm{EC}=([\mathrm{ATP}]+0.5[\mathrm{ADP}]) /([\mathrm{ATP}]+[\mathrm{ADP}]+[\mathrm{AMP}]
$$

The EC value represents the energy resources of a cell as a function of the concentration of nucleotides. A 
biological system is fully charged when ATP dominates over other adenine nucleotides, and the corresponding $\mathrm{EC}$ is close to one.

\section{List of abbreviations}

AD: Alzheimer's disease; [ $\left.{ }^{3} H\right] D A:\left[{ }^{3} H\right]$ dopamine; DMSO: dimethylsulfoxide; DOPAC: 3,4-dihydroxyphenylacetic acid; EC: energy charge; EFS: electrical field stimulation; 5-HIAA: 5-hydroxyindoleacetic acid; 5-HT: Serotonin; HVA: homovanillic acid; HD: Huntington's disease; LDH: lactate dehydrogenase; MAP2: microtubule-associated protein 2; 3-MT: 3-methoxytyramine; MPTP: 1 methyl-4-phenyl-1,2,3,6-tetrahydropyridine; MTT: 3-[4,5-dimethylthiazol-2-yl]2,5-diphenyl tetrazolium bromide; NE: norepinephrine; PD: Parkinson's disease; PBS: phosphate buffered saline.

\section{Acknowledgements}

This study was supported by grants of the Hungarian Research and Development Fund (NN79957 to B.S.) and the Hungarian Medical Research Council (ETT 05-102 to B.S.). The authors are grateful to Ms. Zsuzsanna Körössy who performed the in vivo animal treatments and the $\left[{ }^{3} \mathrm{H}\right]$ dopamine release experiments.

\section{Author details}

'Laboratory of Molecular Pharmacology, Institute of Experimental Medicine, Hungarian Academy of Sciences, H-1083 Budapest, Szigony u. 43, Hungary. ${ }^{2}$ Laboratory of Cellular and Developmental Neurobiology, Institute of Experimental Medicine, Hungarian Academy of Sciences, H-1083 Budapest, Szigony u. 43, Hungary.

\section{Authors' contributions}

$\mathrm{ZH}$ and $\mathrm{CC}$ performed the gene expression studies. $\mathrm{ZH}$ and FG maintained cell cultures and performed the cell viability assays. MB carried out the HPLC analyses. EM established the primary midbrain culture. AK performed the immunostaining experiments. ZH, MB, CC, FG, EM and AK drafted the manuscript. BS designed and coordinated the study and finalized the manuscript. All authors read and approved the final manuscript.

\section{Competing interests}

The authors declare that they have no competing interests.

Received: 27 August 2010 Accepted: 4 May 2011 Published: 4 May 2011

\section{References}

1. Franke $H$, Illes $P$ : Involvement of $P 2$ receptors in the growth and survival of neurons in the CNS. Pharmacol Ther 2006, 109:297-324.

2. Skaper SD, Debetto P, Giusti P: The P2X7 purinergic receptor: from physiology to neurological disorders. FASEB J 2010, 24:337-345.

3. Sperlagh B, Vizi ES, Wirkner K, lles P: P2X7 receptors in the nervous system. Prog Neurobiol 2006, 78:327-346.

4. Surprenant A, North RA: Signaling at purinergic P2X receptors. Annu Rev Physiol 2009, 71:333-359.

5. North RA, Surprenant A: Pharmacology of cloned P2X receptors. Annu Rev Pharmacol Toxicol 2000, 40:563-580.

6. Nicke A, Kuan $\mathrm{YH}$, Masin M, Rettinger J, Marquez-Klaka B, Bender O, Gorecki DC, Murrell-Lagnado RD, Soto F: A functional P2X7 splice variant with an alternative transmembrane domain 1 escapes gene inactivation in P2X7 knock-out mice. J Biol Chem 2009, 284:25813-25822.

7. Anderson $C M$, Nedergaard $\mathrm{M}$ : Emerging challenges of assigning $\mathrm{P} 2 \mathrm{X} 7$ receptor function and immunoreactivity in neurons. Trends in neurosciences 2006, 29:257-262.

8. Alloisio S, Cervetto C, Passalacqua M, Barbieri R, Maura G, Nobile M, Marcoli M: Functional evidence for presynaptic P2X7 receptors in adult rat cerebrocortical nerve terminals. FEBS Lett 2008, 582:3948-3953.

9. Papp L, Vizi ES, Sperlagh B: Lack of ATP-evoked GABA and glutamate release in the hippocampus of P2X7 receptor-/- mice. Neuroreport 2004, 15:2387-2391.

10. Sperlagh B, Kofalvi A, Deuchars J, Atkinson L, Milligan CJ, Buckley NJ, Vizi ES: Involvement of P2X7 receptors in the regulation of neurotransmitter release in the rat hippocampus. J Neurochem 2002, 81:1196-1211.
11. Bianco F, Ceruti S, Colombo A, Fumagalli M, Ferrari D, Pizzirani C, Matteoli M, Di Virgilio F, Abbracchio MP, Verderio C: A role for P2X7 in microglial proliferation. J Neurochem 2006, 99:745-758.

12. Monif $M$, Reid CA, Powell KL, Smart ML, Williams DA: The P2X7 receptor drives microglial activation and proliferation: a trophic role for P2X7R pore. J Neurosci 2009, 29:3781-3791.

13. Skaper SD, Facci L, Culbert AA, Evans NA, Chessell I, Davis JB, Richardson JC $\mathrm{P} 2 \mathrm{X}(7)$ receptors on microglial cells mediate injury to cortical neurons in vitro. Glia 2006, 54:234-242

14. Ferrari D, Pizzirani C, Adinolfi E, Lemoli RM, Curti A, Idzko M, Panther E, Di Virgilio F: The $\mathrm{P} 2 \mathrm{X} 7$ receptor: a key player in IL-1 processing and release. J Immunol 2006, 176:3877-3883.

15. Witting A, Walter L, Wacker J, Moller T, Stella N: P2X7 receptors control 2arachidonoylglycerol production by microglial cells. Proc Natl Acad Sci USA 2004, 101:3214-3219.

16. Walter $L$, Dinh $T$, Stella N: ATP induces a rapid and pronounced increase in 2-arachidonoylglycerol production by astrocytes, a response limited by monoacylglycerol lipase. J Neurosci 2004, 24:8068-8074.

17. Peng W, Cotrina ML, Han X, Yu H, Bekar L, Blum L, Takano T, Tian GF, Goldman SA, Nedergaard M: Systemic administration of an antagonist of the ATP-sensitive receptor P2X7 improves recovery after spinal cord injury. Proc Natl Acad Sci USA 2009, 106:12489-12493.

18. Wang X, Arcuino G, Takano T, Lin J, Peng WG, Wan P, Li P, Xu Q, Liu QS, Goldman SA, Nedergaard M: P2X7 receptor inhibition improves recovery after spinal cord injury. Nat Med 2004, 10:821-827.

19. Ryu JK, McLarnon JG: Block of purinergic P2X(7) receptor is neuroprotective in an animal model of Alzheimer's disease. Neuroreport 2008, 19:1715-1719.

20. Diaz-Hernandez M, Diez-Zaera M, Sanchez-Nogueiro J, Gomez-Villafuertes R, Canals JM, Alberch J, Miras-Portugal MT, Lucas JJ: Altered P2X7-receptor level and function in mouse models of Huntington's disease and therapeutic efficacy of antagonist administration. FASEB J 2009, 23:1893-1906.

21. Lammer A, Gunther A, Beck A, Krugel U, Kittner H, Schneider D, Illes P, Franke $\mathrm{H}$ : Neuroprotective effects of the P2 receptor antagonist PPADS on focal cerebral ischaemia-induced injury in rats. Eur J Neurosci 2006, 23:2824-2828.

22. Melani A, Amadio S, Gianfriddo M, Vannucchi MG, Volonte C, Bernardi G, Pedata F, Sancesario G: P2X7 receptor modulation on microglial cells and reduction of brain infarct caused by middle cerebral artery occlusion in rat. J Cereb Blood Flow Metab 2006, 26:974-982.

23. Le Feuvre R, Brough D, Rothwell N: Extracellular ATP and P2X7 receptors in neurodegeneration. Eur J Pharmacol 2002, 447:261-269.

24. Le Feuvre RA, Brough D, Touzani O, Rothwell NJ: Role of P2X7 receptors in ischemic and excitotoxic brain injury in vivo. J Cereb Blood Flow Metab 2003, 23:381-384.

25. Matute C, Torre I, Perez-Cerda F, Perez-Samartin A, Alberdi E, Etxebarria $E_{t}$ Arranz AM, Ravid R, Rodriguez-Antiguedad A, Sanchez-Gomez M, Domercq M: P2X(7) receptor blockade prevents ATP excitotoxicity in oligodendrocytes and ameliorates experimental autoimmune encephalomyelitis. J Neurosci 2007, 27:9525-9533.

26. Chen L, Brosnan CF: Exacerbation of experimental autoimmune encephalomyelitis in P2X7R-/- mice: evidence for loss of apoptotic activity in lymphocytes. J Immunol 2006, 176:3115-3126.

27. Witting A, Chen L, Cudaback E, Straiker A, Walter L, Rickman B, Moller T, Brosnan C, Stella N: Experimental autoimmune encephalomyelitis disrupts endocannabinoid-mediated neuroprotection. Proc Natl Acad Sci USA 2006, 103:6362-6367.

28. Heine C, Wegner A, Grosche J, Allgaier C, Illes P, Franke H: P2 receptor expression in the dopaminergic system of the rat brain during development. Neuroscience 2007, 149:165-181.

29. Amadio S, Montilli C, Picconi B, Calabresi P, Volonte C: Mapping P2X and $\mathrm{P} 2 \mathrm{Y}$ receptor proteins in striatum and substantia nigra: An immunohistological study. Purinergic Signal 2007, 3:389-398.

30. Miras-Portugal MT, Diaz-Hernandez M, Giraldez L, Hervas C, GomezVillafuertes R, Sen RP, Gualix J, Pintor J: P2X7 receptors in rat brain: presence in synaptic terminals and granule cells. Neurochem Res 2003, 28:1597-1605.

31. Cavaliere F, Dinkel K, Reymann K: Microglia response and P2 receptor participation in oxygen/glucose deprivation-induced cortical damage. Neuroscience 2005, 136:615-623. 
32. Jun DJ, Kim J, Jung SY, Song R, Noh JH, Park YS, Ryu SH, Kim JH, Kong YY Chung JM, Kim KT: Extracellular ATP mediates necrotic cell swelling in SN4741 dopaminergic neurons through P2X7 receptors. J Biol Chem 2007, 282:37350-37358

33. Milusheva E, Baranyi M, Kormos E, Hracsko Z, Sylvester Vizi E, Sperlagh B: The effect of antiparkinsonian drugs on oxidative stress induced pathological $\left[{ }^{3} \mathrm{H}\right]$ dopamine efflux after in vitro rotenone exposure in rat striatal slices. Neuropharmacology 2010, 58:816-825.

34. Cheng B, Yang X, Chen C, Cheng D, Xu X, Zhang X: D-betahydroxybutyrate prevents MPP+-induced neurotoxicity in PC12 cells. Neurochem Res 2010, 35:444-451.

35. Sai $Y, W u$ Q, Le W, Ye F, Li Y, Dong Z: Rotenone-induced PC12 cell toxicity is caused by oxidative stress resulting from altered dopamine metabolism. Toxicol In Vitro 2008, 22:1461-1468.

36. Shimoke K, Kudo M: 1-Methyl-4-phenyl-1,2,3,6-tetrahydropyridine has a transient proliferative effect on PC12h cells and nerve growth factor additively promotes this effect: possible involvement of distinct mechanisms of activation of MAP kinase family proteins. Brain Res Dev Brain Res 2002, 133:105-114.

37. Jiang $L H$, Mackenzie $A B$, North RA, Surprenant A: Brilliant blue $G$ selectively blocks ATP-gated rat P2X(7) receptors. Mol Pharmacol 2000, 58:82-88.

38. Michel AD, Chambers $L$, Walter DS: Negative and positive allosteric modulators of the $\mathrm{P} 2 \mathrm{X}(7)$ receptor. Br J Pharmacol 2008, 153:737-750.

39. Amadio S, D'Ambrosi N, Cavaliere F, Murra B, Sancesario G, Bernardi G, Burnstock $\mathrm{G}$, Volonte $\mathrm{C}$ : $\mathrm{P} 2$ receptor modulation and cytotoxic function in cultured CNS neurons. Neuropharmacology 2002, 42:489-501.

40. Baranyi M, Milusheva E, Vizi ES, Sperlagh B: Chromatographic analysis of dopamine metabolism in a Parkinsonian model. J Chromatogr A 2006, 1120:13-20.

41. Milusheva E, Baranyi M, Kittel A, Sperlagh B, Vizi ES: Increased sensitivity of striatal dopamine release to $\mathrm{H} 2 \mathrm{O} 2$ upon chronic rotenone treatment. Free Radic Biol Med 2005, 39:133-142.

42. Sherer TB, Kim JH, Betarbet R, Greenamyre JT: Subcutaneous rotenone exposure causes highly selective dopaminergic degeneration and alphasynuclein aggregation. Exp Neurol 2003, 179:9-16

43. Sperlagh B, Illes P: Purinergic modulation of microglial cell activation. Purinergic Signal 2007, 3:117-127.

44. Takenouchi T, Sekiyama K, Sekigawa A, Fujita M, Waragai M, Sugama S, Iwamaru Y, Kitani H, Hashimoto M: P2X7 receptor signaling pathway as a therapeutic target for neurodegenerative diseases. Arch Immunol Ther Exp (Warsz) 2010, 58:91-96.

45. Weinhold K, Krause-Buchholz U, Rodel G, Kasper M, Barth K: Interaction and interrelation of $\mathrm{P} 2 \mathrm{X} 7$ and $\mathrm{P} 2 \mathrm{X} 4$ receptor complexes in mouse lung epithelial cells. Cell Mol Life Sci 2010, 67:2631-2642.

46. Cheewatrakoolpong B, Gilchrest H, Anthes JC, Greenfeder S: Identification and characterization of splice variants of the human P2X7 ATP channel. Biochem Biophys Res Commun 2005, 332:17-27.

47. Feng $Y H$, Li X, Wang L, Zhou L, Gorodeski Gl: A truncated P2X7 receptor variant (P2X7-j) endogenously expressed in cervical cancer cells antagonizes the full-length $\mathrm{P} 2 \mathrm{X} 7$ receptor through heterooligomerization. J Biol Chem 2006, 281:17228-17237.

48. D'Alimonte I, Ciccarelli R, Di lorio P, Nargi E, Buccella S, Giuliani P, Rathbone MP, Jiang S, Caciagli F, Ballerini P: Activation of $\mathrm{P} 2 \mathrm{X}(7)$ receptors stimulates the expression of $\mathrm{P} 2 \mathrm{Y}(2)$ receptor mRNA in astrocytes cultured from rat brain. Int J Immunopathol Pharmacol 2007, 20:301-316.

49. Chorna NE, Santiago-Perez LI, Erb L, Seye Cl, Neary JT, Sun GY, Weisman GA, Gonzalez FA: P2Y receptors activate neuroprotective mechanisms in astrocytic cells. J Neurochem 2004, 91:119-132.

50. Ortega F, Perez-Sen R, Delicado EG, Miras-Portugal MT: P2X7 nucleotide receptor is coupled to GSK-3 inhibition and neuroprotection in cerebellar granule neurons. Neurotox Res 2009, 15:193-204.

51. Ortega F, Perez-Sen R, Morente V, Delicado EG, Miras-Portugal MT: P2X7 NMDA and BDNF receptors converge on GSK3 phosphorylation and cooperate to promote survival in cerebellar granule neurons. Cell Mol Life Sci 2010, 67:1723-1733.

52. Klegeris A, Bissonnette CJ, McGeer PL: Reduction of human monocytic cell neurotoxicity and cytokine secretion by ligands of the cannabinoid-type CB2 receptor. Br J Pharmacol 2003, 139:775-786.

53. Marsicano G, Goodenough S, Monory K, Hermann H, Eder M, Cannich A, Azad SC, Cascio MG, Gutierrez SO, van der Stelt M, et al: CB1 cannabinoid receptors and on-demand defense against excitotoxicity. Science 2003, 302:84-88.

54. Panikashvili D, Simeonidou C, Ben-Shabat S, Hanus L, Breuer A, Mechoulam R, Shohami E: An endogenous cannabinoid (2-AG) is neuroprotective after brain injury. Nature 2001, 413:527-531.

55. Garcia-Arencibia M, Gonzalez S, de Lago E, Ramos JA, Mechoulam R, Fernandez-Ruiz J: Evaluation of the neuroprotective effect of cannabinoids in a rat model of Parkinson's disease: importance of antioxidant and cannabinoid receptor-independent properties. Brain Res 2007, 1134:162-170.

56. Lastres-Becker I, Molina-Holgado F, Ramos JA, Mechoulam R, FernandezRuiz J: Cannabinoids provide neuroprotection against 6hydroxydopamine toxicity in vivo and in vitro: relevance to Parkinson's disease. Neurobiol Dis 2005, 19:96-107.

57. Jimenez S, Baglietto-Vargas D, Caballero C, Moreno-Gonzalez I, Torres M, Sanchez-Varo R, Ruano D, Vizuete M, Gutierrez A, Vitorica J: Inflammatory response in the hippocampus of PS1M146L/APP751SL mouse model of Alzheimer's disease: age-dependent switch in the microglial phenotype from alternative to classic. J Neurosci 2008, 28:11650-11661.

58. Solle M, Labasi J, Perregaux DG, Stam E, Petrushova N, Koller BH, Griffiths RJ Gabel CA: Altered cytokine production in mice lacking P2X(7) receptors. J Biol Chem 2001, 276:125-132.

59. Papp L, Balazsa T, Kofalvi A, Erdelyi F, Szabo G, Vizi ES, Sperlagh B: P2X receptor activation elicits transporter-mediated noradrenaline release from rat hippocampal slices. J Pharmacol Exp Ther 2004, 310:973-980.

60. Brautigam VM, Frasier C, Nikodemova M, Watters JJ: Purinergic receptor modulation of BV-2 microglial cell activity: potential involvement of p38 MAP kinase and CREB. J Neuroimmunol 2005, 166:113-125.

61. Pfaffl MW: A new mathematical model for relative quantification in realtime RT-PCR. Nucleic Acids Res 2001, 29:e45.

62. Lowry OH, Rosebrough NJ, Farr AL, Randall RJ: Protein measurement with the Folin phenol reagent. J Biol Chem 1951, 193:265-275.

63. Atkinson DE: The energy charge of the adenylate pool as a regulatory parameter. Interaction with feedback modifiers. Biochemistry 1968, 7:4030-4034

doi:10.1186/1750-1326-6-28

Cite this article as: Hracskó et al:: Lack of neuroprotection in the absence of $\mathrm{P} 2 \mathrm{X} 7$ receptors in toxin-induced animal models of Parkinson's disease. Molecular Neurodegeneration 2011 6:28.

\section{Submit your next manuscript to BioMed Central and take full advantage of:}

- Convenient online submission

- Thorough peer review

- No space constraints or color figure charges

- Immediate publication on acceptance

- Inclusion in PubMed, CAS, Scopus and Google Scholar

- Research which is freely available for redistribution

Submit your manuscript at www.biomedcentral.com/submit
C Biomed Central 